\title{
Structure-Activity Relationships of Pyridoxal Phosphate Derivatives as Potent and Selective Antagonists of $\mathrm{P}_{2} \mathrm{X}_{1}$ Receptors
}

\author{
Yong-Chul Kim, ' Sean G. Brown, ${ }^{\prime}$ T. Kendall Harden, J osé L. Boyer,§ George Dubyak," Brian F. King, \\ Geoffrey Burnstock, ${ }^{\ddagger}$ and Kenneth A. J acobson*,†
}

Molecular Recognition Section, Laboratory of Bioorganic Chemistry, National Institute of Diabetes and Digestive and Kidney Diseases, NIH, Bethesda, Maryland 20892-0810, Autonomic Neuroscience Institute, Royal Free and University College Medical School, Rowland Hill Street, London NW3 2PF, U.K., Department of Pharmacology, University of North Carolina School of Medicine, Chapel Hill, North Carolina 27599-7365, and Department of Physiology and Biophysics, Case Western Reserve University School of Medicine, Cleveland, Ohio 44106

Received August 19, 1999

\begin{abstract}
Novel analogues of the P2 receptor antagonist pyridoxal-5'-phosphate 6-azophenyl-2',5'disulfonate (2) were synthesized and studied as antagonists in functional assays at recombinant rat $\mathrm{P} 2 \mathrm{X}_{1}, \mathrm{P} 2 \mathrm{X}_{2}$, and $\mathrm{P} 2 \mathrm{X}_{3}$ receptors expressed in Xenopus oocytes (ion flux stimulation) and at turkey erythrocyte $P 2 Y_{1}$ receptors (phosphol ipase $C$ activation). Selected compounds were also evaluated as antagonists of ion flux and the opening of a large pore at the recombinant human $\mathrm{P}_{2} \mathrm{X}_{7}$ receptor. Modifications were made in the 4-aldehyde and 5'-phosphate groups of the pyridoxal moiety: i.e. a $\mathrm{CH}_{2} \mathrm{OH}$ group at the 4-position in pyridoxine was either condensed as a cyclic phosphate or phosphorylated separately to form a bisphosphate, which reduced potency at P2 receptors. 5-Methylphosphonate substitution, anticipated to increase stability to hydrolysis, preserved $\mathrm{P} 2$ receptor potency. At the 6-position, halo, carboxylate, sulfonate, and phosphonate variations made on the phenylazo ring modulated potency at P 2 receptors. The p-carboxyphenylazo anal ogue, 4, of phosphate 2 displayed an $I C_{50}$ value of $9 \mathrm{nM}$ at recombinant $P 2 X_{1}$ receptors and was 1300-, 16-, and $>10000$-fold selective for $P 2 X_{1}$ versus $P 2 X_{2}, P 2 X_{3}$, and $\mathrm{P}_{2} \mathrm{Y}_{1}$ subtypes, respectively. The corresponding 5-methyl phosphonate was equipotent at $\mathrm{P} 2 \mathrm{X}_{1}$ receptors. The 5-methylphosphonate analogue containing a 6-[3,5-bis(methylphosphonate)]phenylazo moiety, 9, had I $C_{50}$ values of 11 and $25 \mathrm{nM}$ at recombinant $\mathrm{P} 2 \mathrm{X}_{1}$ and $\mathrm{P} 2 \mathrm{X}_{3}$ receptors, respectively. The analogue containing a phenylazo 4-phosphonate group, 11, was also very potent at both $\mathrm{P} 2 \mathrm{X}_{1}$ and $\mathrm{P} 2 \mathrm{X}_{3}$ receptors. However, the corresponding 2,5-disulfonate anal ogue, 10, was 28-fold selective for $\mathrm{P} 2 \mathrm{X}_{1}$ versus $\mathrm{P} 2 \mathrm{X}_{3}$ receptors. None of the analogues were more potent at $\mathrm{P}_{2} \mathrm{X}_{7}$ and $\mathrm{P} 2 \mathrm{Y}_{1}$ receptors than $\mathbf{2}$, which acted in the micromolar range at these two subtypes.
\end{abstract}

\section{Introduction}

Adenine and uracil 5'-nucleotides act in cellular signaling in the nervous, muscular, cardiovascular, renal, and immune systems, through the activation of P2 receptors. ${ }^{1-3}$ These nucleotide receptors consist of two families of distinct structure and function: $\mathrm{P} 2 \mathrm{X}$ ligand-gated cation channels and $G$ protein-coupled $P 2 Y$ receptors. ${ }^{4} \mathrm{P}_{2} \mathrm{X}_{1-7}$ and $\mathrm{P} 2 \mathrm{Y}_{1,2,4,6,11}$ designations have been unambiguously assigned to mammalian nucleotide receptors, ${ }^{5-7}$ although there is still uncertainty about the correspondence of these sequences to the pharmacological phenotypes described prior to P2 receptor cloning. ${ }^{8}$

The therapeutic potential of potent and selective agonists and antagonists of $\mathrm{P} 2$ receptors has been discussed, although in mainly hypothetical terms due to the current lack of such agents. ${ }^{9}$ For example, activation of the $\mathrm{P} 2 \mathrm{X}_{1}$ subtype mediates vasoconstriction at vascular smooth muscle, thus selective antagonists

* Correspondence to: Dr. K. A. J acobson, Chief, MRS, Bldg. 8A, Rm. B1A-19, NIH, NIDDK, LBC, Bethesda, MD 20892-0810. Tel: (301) 4969024. Fax: (301) 480-8422. E-mail: kajacobs@helix.nih.gov

$+\mathrm{NIH}$.

₹ Royal Free Hospital School of Medicine.

$\S$ University of North Carolina School of Medicine.

" Case Western Reserve University School of Medicine. may be antihypertensive. The $\mathrm{P} 2 \mathrm{Y}_{1}$ subtype participates in blood platelet aggregation, thus selective antagonists may be useful in regulating hemostasis. It appears that activation of the $\mathrm{P} 2 \mathrm{X}_{3}$ receptor subtype mediates nociception via the dorsal root ganglia, thus a selective antagonist may be antinociceptive. ${ }^{10,11}$ Activation of the $\mathrm{P} 2 \mathrm{X}_{7}$ receptor subtype induces apoptosis in the immune and inflammatory system, thus selective antagonists may also be useful therapeutically. ${ }^{12}$

Derivatives of pyridoxal-5'-phosphate in which an azoaryl group is present at the 6-position were shown to be nonsel ective $\mathrm{P} 2$ receptor antagonists. ${ }^{13}$ Compounds 1 (pyridoxal- $\alpha^{5}$-phosphate-6-azophenyl-2',4'-disulfonic acid) and $\mathbf{2}$ (the 2,5-disulfonate isomer) (Figure 1) have been studied as antagonists of adenine nucleotides at the turkey erythrocyte $\mathrm{P}_{2} \mathrm{Y}_{1}$ receptor ${ }^{14,15}$ and at $\mathrm{P} 2 \mathrm{X}_{1-}$ like receptors in the rabbit vas deferens, ${ }^{16}$ urinary bladder, ${ }^{17}$ isolated blood vessels, ${ }^{18}$ guinea-pig isolated vas deferens, ${ }^{19}$ and perfused rat mesenteric arterial bed. ${ }^{20} \mathbf{1}$ was also found to be a weak antagonist at the $\mathrm{P} 2 \mathrm{X}_{7}$ receptor in mouse microglial cells. ${ }^{21}$ Both $\mathbf{1}$ and $\mathbf{2}$ have been shown to be antagonists of ATP (adenosine5 -triphosphate) at $\mathrm{P} 2 \mathrm{X}_{3}$-like receptors in sensory neurons. ${ }^{22-24}$

The present study demonstrates that both subtype 


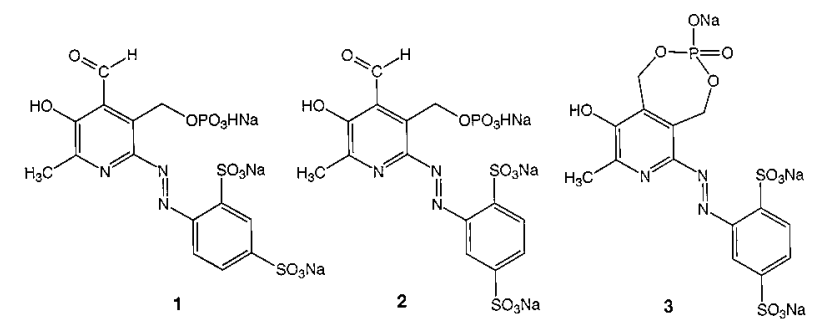

Figure 1. Structures of azo derivatives of pyridoxal-5'phosphate (1 and $\mathbf{2}$ ) and a cyclic pyridoxine- $\alpha^{4,5}$-monophosphate derivative (3), all of which act as P2 receptor antagonists.

Table 1. MS and HPLCa Characterization of the Pyridoxal-Phosphate Analogues Synthesized

\begin{tabular}{|c|c|c|c|c|c|c|}
\hline \multirow[b]{2}{*}{ no. } & \multirow[b]{2}{*}{ formula } & \multirow[b]{2}{*}{$\%$ yield } & \multicolumn{2}{|c|}{$\mathrm{FAB}\left(\mathrm{M}-\mathrm{H}^{+}\right)$} & \multicolumn{2}{|c|}{$\operatorname{HPLC}\left(t_{R}, \min \right)$} \\
\hline & & & calcd & found & $A$ & B \\
\hline & $\mathrm{C}_{15} \mathrm{H}_{14} \mathrm{~N}_{3} \mathrm{O}_{7} \mathrm{P}$ & 71 & 378.0491 & 378.0494 & 4.6 & 10.5 \\
\hline & & & & & & \\
\hline & $\mathrm{C}_{16} \mathrm{H}_{20} \mathrm{~N}$ & & $522 .($ & $522 . c$ & & \\
\hline & $\mathrm{C}_{14} \mathrm{H}_{14} \mathrm{~N}_{3} \mathrm{l}$ & & & & & 0.0 \\
\hline & $\mathrm{C}_{14} \mathrm{H}$ & 5 & & & 10 & 2.8 \\
\hline & $\mathrm{C}_{15} \mathrm{H}_{14} \mathrm{~N}_{3} \mathrm{O}_{7} \mathrm{P}$ & 43 & & & & 10.2 \\
\hline & $\mathrm{C}_{16} \mathrm{H}_{14} \mathrm{~N}_{3} \mathrm{Na}_{2} \mathrm{O}_{12} \mathrm{PS}$ & 100 & & & & 13.4 \\
\hline & $\mathrm{C}_{14} \mathrm{H}_{1}$ & 28 & & & & 10.1 \\
\hline & $\mathrm{C}_{8} \mathrm{H}_{13} \mathrm{NO}_{9} \mathrm{P}_{2}$ & & & & 4 & 8.7 \\
\hline & $\mathrm{C}_{14} \mathrm{H}_{15} \mathrm{~N}_{3} \mathrm{Na}_{2} \mathrm{O}_{15} \mathrm{P}_{2}$ & 8 & & & 5 & 17.1 \\
\hline & $\mathrm{C}_{14} \mathrm{H}_{16} \mathrm{ClN}_{3}$ & 73 & 545 & & 7. & 14.3 \\
\hline & & 81 & 432.0362 & 432.0339 & 6.7 & 12.8 \\
\hline
\end{tabular}

a System $A$ was $0.1 \mathrm{M}$ triethylammonium acetate buffer: $\mathrm{CH}_{3} \mathrm{CN}$ $=95: 5$ to $40: 60$ for $20 \mathrm{~min}$ with flow rate $1 \mathrm{~mL} / \mathrm{min}$. System $B$ was $5 \mathrm{mM}$ tetrabutylammonium phosphate buffer: $\mathrm{CH}_{3} \mathrm{CN}$ 80:20 to $40: 60$ in 20 min with flow rate $1 \mathrm{~mL} / \mathrm{min}$.

selectivity and high affinity can be achieved through structural modification of the pyridoxal-5'-phosphate series of antagonists. Recently we reported ${ }^{14}$ that the cyclic pyridoxine- $\alpha^{4,5}$-monophosphate corresponding to $\mathbf{2}$, i.e. compound $\mathbf{3}$, was a weak but sel ective antagonist of ATP-evoked responses at rat $\mathrm{P}_{2} \mathrm{X}_{1}$ receptors. Furthermore, this cyclic phosphate was inactive at phospholipase C-coupled P2Y receptors, at the adenylate cyclase-coupled P2Y receptors in rat C6 glioma cells, and at adenosine receptors. In the present study, additional anal ogues of both pyridoxal and pyridoxine are explored, resulting in enhanced potency and/or selectivity at $\mathrm{P}_{2} \mathrm{X}_{1}$ receptors. In certain analogues, the polyanionic nature of the derivatives is diminished, and in other analogues the stability is potentially enhanced through the introduction of a phosphonate linkage. As antagonists, many of the compounds were found to be more freely reversible, in comparison to $\mathbf{1}$ and $\mathbf{2}$. Some of the present 5'phosphate and 5'-phosphonate derivatives were reported in a preliminary study ${ }^{25}$ and are now characterized more fully at a broader range of recombinant P2X receptor subtypes.

\section{Results}

We have introduced 5'-phosphonate linkages, ${ }^{25}$ cyclic phosphate diesters, ${ }^{14}$ bisphosphates, and modified functional groups on the phenylazo moiety (Table 1), with the aim of developing more potent and selective antagonists for P2 receptor subtypes. Halo, carboxylate, sulfonate, and phosphonate (Scheme 1) variations were made on the phenyl ring (compounds 4-11). 5-Methyl phosphonate and 5-ethylphosphonate substitutions of the methylphosphate moiety were introduced. Ana-
Scheme 1. Synthesis of Anilinephosphonic Acid Derivatives $^{\mathrm{a}}$<smiles>O=[N+]([O-])c1cc(CO)cc(CBr)c1</smiles>

25
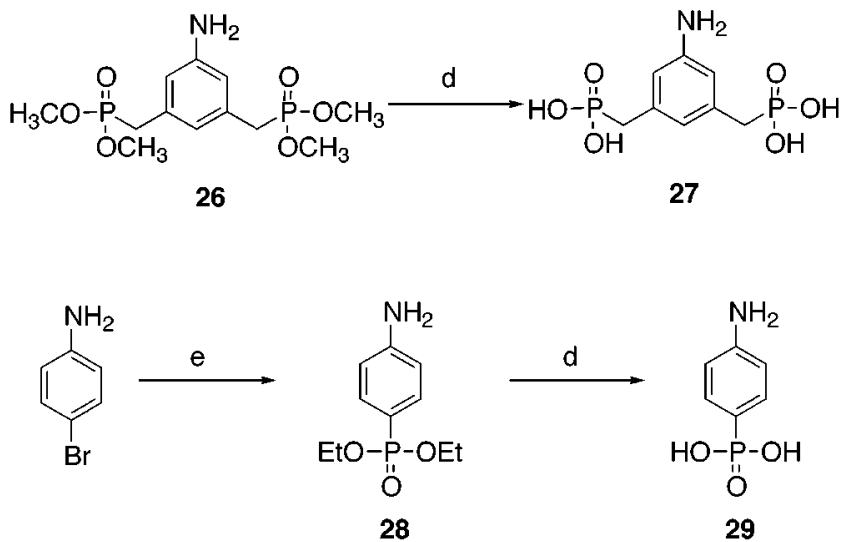

a Reagents: (a) $(\mathrm{Ph})_{3} \mathrm{P}, \mathrm{CBr}_{4}$ in ether, $25{ }^{\circ} \mathrm{C}, 12 \mathrm{~h}, 52 \%$; (b) $\mathrm{P}\left(\mathrm{OCH}_{3}\right)_{3}, 80{ }^{\circ} \mathrm{C}, 6 \mathrm{~h}, 94 \%$; (c) $\mathrm{Pd} / \mathrm{C}, \mathrm{H}_{2}$ in $\mathrm{MeOH}, 1$ atm, $25{ }^{\circ} \mathrm{C}, 1$ h, 100\%; (d) TMS-Br in $\mathrm{CH}_{3} \mathrm{CN}, 25^{\circ} \mathrm{C}, 12 \mathrm{~h}, 99 \%$; (e) (EtO) ${ }_{2} \mathrm{P}(\mathrm{O}) \mathrm{H}$, triethylamine, tetrakis $\left((\mathrm{Ph})_{3} \mathrm{P}\right) \mathrm{Pd}(0)$ in toluene, $90{ }^{\circ} \mathrm{C}, 16 \mathrm{~h}, 18 \%$.

logues of the P2 receptor antagonists pyridoxal-5'phosphate and 6-azophenyl-2',5'-disulfonate derivative (2), in which the phosphate group was cyclized by esterification to a $\mathrm{CH}_{2} \mathrm{OH}$ group at the 4-position in pyridoxine, were synthesized (compounds 13-16). Finally, bisphosphate derivatives of pyridoxine (compounds 18-20) were prepared (Scheme 2).

The new derivatives were characterized using NMR and high-resolution mass spectroscopy, and purity of 95-98\% was demonstrated using high-pressure liquid chromatography (HPLC) in two different solvent systems. The compounds were tested in ion channel assays ${ }^{26}$ of ATP-induced current at recombinant rat $\mathrm{P} 2 \mathrm{X}_{1}$, $\mathrm{P} 2 \mathrm{X}_{2}$, and $\mathrm{P} 2 \mathrm{X}_{3}$ receptors, expressed in Xenopus oocytes, using the twin-electrode voltage-clamping technique.

Several compounds $(\mathbf{4}, \mathbf{8}, \mathbf{1 0})$ were previously reported to antagonize agonist-induced cation flux at recombinant $\mathrm{P} 2 \mathrm{X}_{2}$ receptors, with $\mathrm{IC}_{50}$ values of $1-10 \mu \mathrm{M}$. Most of the compounds were weak or inactive as antagonists at the turkey erythrocyte $\mathrm{P}_{2} \mathrm{Y}_{1}$ receptor (Table 2), in activation of phospholipase $C$ activity 27,28 induced by 10 nM 2-methylthioadenosine-5'-diphosphate (2-M eSADP). Compound $\mathbf{1 1}$ displayed an IC $\mathrm{C}_{50}$ value of $27 \mu \mathrm{M}$.

In inhibition of the inward current elicited by ATP at recombinant $\mathrm{P} 2 \mathrm{X}_{1}$ receptors, compounds $4-\mathbf{1 1}$, with $\mathrm{IC}_{50}$ values of 9-42 $\mathrm{nM}$, were found to be more potent than $\mathbf{1}$ and $\mathbf{2}$ ( $\left(\mathrm{C}_{50}\right.$ values of 99 and $43 \mathrm{nM}$, respectively). The p-carboxylate analogue, $\mathbf{4}$, having a phosphate linkage similar to compound $\mathbf{1}$, selectively inhibited ATP-evoked responses at $\mathrm{P} 2 \mathrm{X}_{1}$ receptors with an $\mathrm{IC}_{50}$ value of $9 \mathrm{nM}$ and displayed 1300-, 16-, and >10000fold selectivity versus $\mathrm{P} 2 \mathrm{X}_{2}, \mathrm{P} 2 \mathrm{X}_{3}$, and $\mathrm{P} 2 \mathrm{Y}_{1}$ receptors, respectively. The corresponding 5-methyl phosphonate analogue, 5, was equipotent to 4 at $\mathrm{P} 2 \mathrm{X}_{1}$ receptors (Figure 2). Thus, compound 5 was 16-fold selective for $\mathrm{P} 2 \mathrm{X}_{1}$ versus $\mathrm{P} 2 \mathrm{X}_{3}$ receptors and 19 -fold sel ective versus $\mathrm{P} 2 \mathrm{X}_{2}$ receptors. The monocarboxylic acid 5-ethyl phosphonate analogue, $\mathbf{6}$, and the dicarboxylic acid deriva- 
Scheme 2. Azo Coupling Reaction of Pyridoxal- and Pyridoxine-Phosphate Derivatives ${ }^{a}$

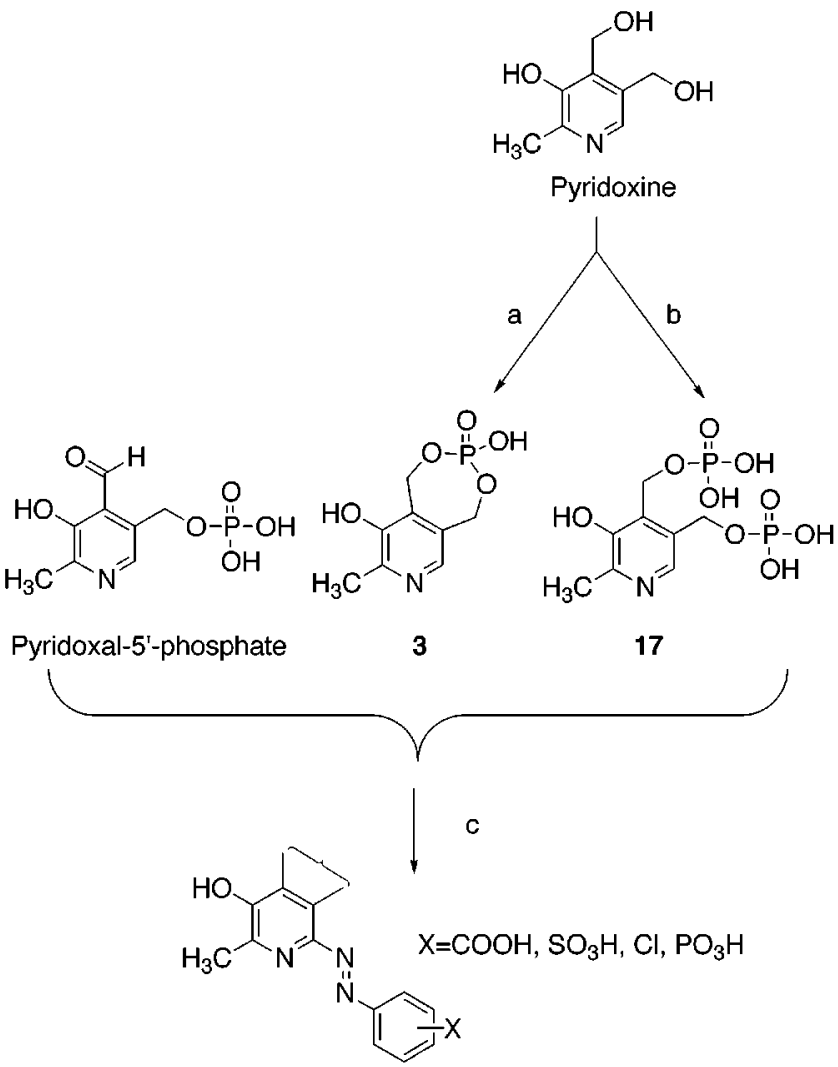

a Reagents: TMS-polyphosphate, benzene, 2 days, either (a) $5 \%$ solution, $40{ }^{\circ} \mathrm{C}$ or (b) $20 \%$ solution, $85{ }^{\circ} \mathrm{C}$; (c) aromatic amine, $\mathrm{NaNO}_{2}, 6 \mathrm{~N} \mathrm{HCl}, \mathrm{pH} 10-11$.

tive, 7, were slightly less potent than $\mathbf{5}$ at $\mathrm{P} 2 \mathrm{X}_{1}$ receptors. Thus, the phosphonate substitution of the 5-methylphosphate moiety, anticipated to increase stability of the analogues to hydrolysis, was found to be well-tolerated at $\mathrm{P} 2 \mathrm{X}$ receptor subtypes.

Phosphonate substitution of the arylazo ring proved to have distinctive effects on potency and selectivity. The $\mathrm{IC}_{50}$ values for the bis(methylphosphonate), 9, at $\mathrm{P} 2 \mathrm{X}_{1}$ and $\mathrm{P}_{2} \mathrm{X}_{3}$ receptors were 11 and $25 \mathrm{nM}$, respectively, in the presence of 1 and $3 \mu \mathrm{M}$ ATP, respectively, thus the $\mathrm{P} 2 \mathrm{X}_{3}$ receptor potency was enhanced. Compound $\mathbf{9}$ was approximately $25-$ and 1300 -fold selective for the $\mathrm{P} 2 \mathrm{X}_{1}$ subtype versus $\mathrm{P} 2 \mathrm{X}_{2}$ and $\mathrm{P} 2 \mathrm{Y}_{1}$ receptors, respectively. Compound 10, a 5-methylphosphonate having the same arylazo sulfonate substitution as compound $\mathbf{2}$, antagonized responses at $\mathrm{P}_{2} \mathrm{X}_{1}$ receptors with an $\mathrm{I} \mathrm{C}_{50}$ value of $12 \mathrm{nM}$. Compound $\mathbf{1 0}$ was $\mathbf{2 8}$-fold sel ective for $\mathrm{P} 2 \mathrm{X}_{1}$ versus $\mathrm{P} 2 \mathrm{X}_{3}$ receptors and 92 -fold sel ective versus $\mathrm{P} 2 \mathrm{X}_{2}$ receptors. A p-phenyl phosphonate derivative, $\mathbf{1 1}$ (Figure 3), was nearly as potent as $\mathbf{9}$ at both $\mathrm{P} 2 \mathrm{X}_{1}$ and $\mathrm{P} 2 \mathrm{X}_{3}$ receptors. Thus, $\mathbf{1 1}$ was 79 -fold sel ective for $\mathrm{P} 2 \mathrm{X}_{1}$

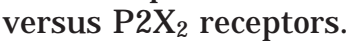

The time course of washout at $\mathrm{P} 2 \mathrm{X}_{1}$ and $\mathrm{P} 2 \mathrm{X}_{3}$ receptors of various potent antagonists was examined (Figure 4). I on channel activity was more rapidly restored, following a 20-min washout, for several active compounds than for $\mathbf{1}$. The percent of control activity recovered for 1 following washout was only $30-40 \%$. The action of $\mathbf{2}$ was fully reversible at both receptors, and most other analogues (4, 8-11), except for compounds 5 and $\mathbf{7}$ with $20-30 \%$, displayed $\geq 75 \%$ recovery.
The cydic phosphates and bisphosphates derived from pyridoxine (3, 13-20) were much less potent than the pyridoxal derivatives in antagonizing the activation of recombinant $\mathrm{P} 2 \mathrm{X}$ receptors expressed in oocytes. The cyclic phosphate anal ogue unsubstituted on the arylazo ring, 16, was inactive.

Compound 15, a cyclic phosphate in which the $3-\mathrm{OH}$ group was acetylated, was completely inactive at $\mathrm{P}_{2} \mathrm{X}_{1}$ receptors, which in comparison to $\mathbf{3}$ demonstrates the importance of the hydroxyl group for receptor recognition.

Selected derivatives of each major class of derivatized pyridoxal-phosphate were also tested for relative antagonistic actions on human recombinant $\mathrm{P}_{2} \mathrm{X}_{7}$ receptors expressed in HEK (human embryonic kidney) 293 cells (Table 3 ). For comparison, three additional analogues of 2, e.g. 21-23, and a nucleotide antagonist of $\mathrm{P}_{2 \mathrm{Y}_{1}}$ receptors, ${ }^{28} \mathbf{2 4}$, were examined in the $\mathrm{P}_{2} \mathrm{X}_{7}$ receptor assay. Activation of this particular P2X family receptor induces two distinct changes in plasma membrane permeability: (1) a rapidly gated cation channel permeable to $\mathrm{Na}^{+}, \mathrm{K}^{+}$, and $\mathrm{Ca}^{2+}$ and (2) a delayed pore that is nonsel ectively permeable to both inorganic ions and various organic molecules up to $800 \mathrm{Da}$ in mass. We first assayed the rapidly gated cation channel activity by assaying the ATP-induced loss of total cell $\mathrm{K}^{+}$. Given the strong inhibitory effects of extracellular divalent cations on $\mathrm{P}_{2} \mathrm{X}_{7}$ receptor function, ${ }^{29}$ these assays were performed using cells suspended in media containing physiological concentrations of $\mathrm{Mg}^{2+}$ and $\mathrm{Ca}^{2+}$ or in media containing no added $\mathrm{Mg}^{2+}$ or $\mathrm{Ca}^{2+}$. In physi ological saline containing $1.5 \mathrm{mM} \mathrm{CaCl}_{2}$ and $1 \mathrm{mM}$ $\mathrm{MgCl}_{2}$, the $\mathrm{EC}_{50}$ for ATP was $1200 \mu \mathrm{M}$ (as assayed by $\mathrm{K}^{+}$efflux). Thus, we used $3 \mathrm{mM}$ ATP as a maximally active concentration of agonist. Under these conditions, $30 \mu \mathrm{M} 2$ produced an $81 \pm 10 \%$ inhibition $(\mathrm{n}=3$ experiments) of the $K^{+}$release triggered by $3 \mathrm{mM}$ ATP. None of the other derivatized pyridoxal-phosphate compounds matched the efficacy of $\mathbf{2}$. Compound $\mathbf{1 0}$ was the next most efficacious inhibitor ( $51 \pm 6 \%$ inhibition) followed by the related compound $\mathbf{2 4}$. A similar rank order of efficacy was observed using HEK-hP2X ${ }_{7}$ cells tested in medium lacking extracellular $\mathrm{Mg}^{2+}$ and $\mathrm{Ca}^{2+}$. The relative efficacy of all inhibitory compounds, including 2, was reduced in the absence of extracellular $\mathrm{Mg}^{2+}$ and $\mathrm{Ca}^{2+}$.

We next assayed the effects of these compounds on ATP-induced pore formation by the $\mathrm{P}_{2} \mathrm{X}_{7}$ receptor. Because pore formation is very strongly repressed by extracellular $\mathrm{Mg}^{2+}$ and $\mathrm{Ca}^{2+}$, these experiments were performed using divalent cation-free saline. Under these assay conditions the $\mathrm{EC}_{50}$ for ATP-induced activation of the pore was $120 \mu \mathrm{M}$. Thus, we used $300 \mu \mathrm{M}$ ATP as a maximally active concentration of the agonist. $30 \mu \mathrm{M}$ 2 completely repressed ATP-induced pore formation. Compound $\mathbf{1 0}$, the phosphonate derivative of $\mathbf{2}$, was equally efficacious ( $100 \%$ inhibition at $30 \mu \mathrm{M}$ ). I ntroduction of bis(methylphosphonate) moieties into the pyridoxal-phosphate core structure (compound 9) further reduced the antagonistic action at the human $\mathrm{P}_{2} \mathrm{X}_{7}$ receptor. Cyclic phosphate (compound 3 ) and bisphosphate derivatives (compounds 18 and 19) were inactive.

The same rank order of efficacy $(\mathbf{2}>\mathbf{1 0}>\mathbf{2 4}>\mathbf{9}, \mathbf{2 2}$, $21 \gg 3,18,19)$ characterized the inhibitory effects of 
Table 2. Structures and Pharmacological Activities of Pyridoxal and Pyridoxine Derivatives (phosphates and phosphonates) at P2 Receptors<smiles>Cc1nc(N=Nc2ccccc2)c([Y](=O)(O)O)c(C(=O)O)c1O</smiles>

$(1,2,4-11)$<smiles>Cc1ncc2c(c1O)COP(=O)(O)OC2</smiles>

(12)<smiles>[X]c1c(C)nc(N=Nc2ccccc2)c2c1COP(=O)(O)OC2</smiles>

(3, 13-16)<smiles>Cc1ncc(COP(=O)(O)O)c(COP(=O)(O)O)c1O</smiles>

(17)<smiles>Cc1nc(N=Nc2ccccc2)c(COP(=O)(O)O)c(COP(=O)(O)O)c1O</smiles>

(18-20)

\begin{tabular}{|c|c|c|c|c|c|c|c|c|c|}
\hline \multirow[b]{2}{*}{ compd } & \multicolumn{5}{|c|}{ positions } & \multicolumn{3}{|c|}{ recombinant $\mathrm{IC}_{50}(\mu \mathrm{M})$} & \multirow{2}{*}{$\begin{array}{l}\text { PLC assay } \\
\mathrm{IC}_{50}(\mu \mathrm{M}) \\
{\mathrm{P} 2 \mathrm{Y}_{1}{ }^{\mathrm{c}}}\end{array}$} \\
\hline & $2^{\prime}$ & $3^{\prime}$ & $4^{\prime}$ & $5^{\prime}$ & $\mathrm{x}$ & $\mathrm{P} 2 \mathrm{X}_{1}^{\mathrm{a}}$ or $\%$ inhib & $\mathrm{P} 2 \mathrm{X}_{2}^{\mathrm{a}}$ & $\mathrm{P} 2 \mathrm{X}_{3}^{\mathrm{a}}$ & \\
\hline$\frac{1}{\text { (PPADS) }}$ & $\mathrm{SO}_{3} \mathrm{H}$ & $\mathrm{H}$ & $\mathrm{SO}_{3} \mathrm{H}$ & $\mathrm{H}$ & $\mathrm{CH}_{2} \mathrm{O}$ & $0.099 \pm 0.006$ & $1.6 \pm 0.1$ & $0.240 \pm 0.038$ & $16.6 \pm 2.5$ \\
\hline (I SOPPADS) & $\mathrm{SO}_{3} \mathrm{H}$ & $\mathrm{H}$ & $\mathrm{H}$ & $\mathrm{SO}_{3} \mathrm{H}$ & $\mathrm{CH}_{2} \mathrm{O}$ & $0.043 \pm 0.018$ & $0.398 \pm 0.125$ & $0.084 \pm 0.004$ & $21.4 \pm 9.0$ \\
\hline $4^{d, f}$ & $\mathrm{H}$ & $\mathrm{H}$ & $\mathrm{COOH}$ & $\mathrm{H}$ & $\mathrm{CH}_{2} \mathrm{O}$ & $0.0094 \pm 0.0017$ & $11.9 \pm 1.4$ & $0.140 \pm 0.011$ & $\sim 100$ \\
\hline 5 & $\mathrm{H}$ & $\mathrm{H}$ & $\mathrm{COOH}$ & $\mathrm{H}$ & $\mathrm{CH}_{2}$ & $0.0081 \pm 0.0021$ & $0.150 \pm 0.020$ & $0.128 \pm 0.019$ & \\
\hline $6^{d}$ & $\mathrm{H}$ & $\mathrm{H}$ & $\mathrm{COOH}$ & $\mathrm{H}$ & $\mathrm{CH}_{2} \mathrm{CH}_{2}$ & $0.020 \pm 0.003$ & $2.4 \pm 0.3$ & $0.145 \pm 0.057$ & $\sim 100$ \\
\hline 7 & $\mathrm{COOH}$ & $\mathrm{H}$ & $\mathrm{H}$ & $\mathrm{COOH}$ & $\mathrm{CH}_{2}$ & $0.037 \pm 0.008$ & $0.486 \pm 0.023$ & $0.330 \pm 0.014$ & \\
\hline $8^{d}$ & $\mathrm{H}$ & $\mathrm{H}$ & $\mathrm{H}$ & $\mathrm{H}$ & $\mathrm{CH}_{2} \mathrm{O}$ & $0.042 \pm 0.006$ & $1.2 \pm 0.2$ & $0.480 \pm 0.090$ & $54 \pm 3$ \\
\hline 9 & & $\mathrm{CH}_{2} \mathrm{P}(\mathrm{O})(\mathrm{OH})_{2}$ & $\mathrm{H}$ & $\mathrm{CH}_{2} \mathrm{P}(\mathrm{O})(\mathrm{OH})_{2}$ & $\mathrm{CH}_{2}$ & $0.011 \pm 0.005$ & $0.280 \pm 0.030$ & $0.025 \pm 0.007$ & $14.5 \pm 2.1$ \\
\hline $10^{d, f}$ & $\mathrm{SO}_{3} \mathrm{H}$ & & $\mathrm{H}$ & $\mathrm{SO}_{3} \mathrm{H}$ & $\mathrm{CH}_{2}$ & $0.012 \pm 0.003$ & $1.1 \pm 0.2$ & $0.340 \pm 0.040$ & $46 \pm 21$ \\
\hline $\begin{array}{l}11^{f} \\
12^{e}\end{array}$ & $\mathrm{H}$ & $\mathrm{H}$ & $\mathrm{P}(\mathrm{O})(\mathrm{OH})_{2}$ & $\mathrm{H}$ & $\mathrm{CH}_{2}$ & $\begin{array}{l}0.012 \pm 0.008 \\
5.9 \pm 1.8\left(\mathrm{EC}_{50}\right)^{\mathrm{g}}\end{array}$ & $\begin{array}{l}0.948 \pm 0.019 \\
\text { inactive }\end{array}$ & $\begin{array}{l}0.036 \pm 0.010 \\
\text { inactive }\end{array}$ & $\begin{array}{l}27 \pm 3 \\
\text { inactive }\end{array}$ \\
\hline $3^{e}$ & $\mathrm{SO}_{3} \mathrm{H}$ & $\mathrm{H}$ & $\mathrm{H}$ & $\mathrm{SO}_{3} \mathrm{H}$ & $\mathrm{H}$ & $10.2 \pm 2.6$ & inactive & $58.3 \pm 0.1$ & inactive \\
\hline 13 & & $\mathrm{H}$ & $\mathrm{H}$ & $\mathrm{SO}_{3} \mathrm{H}$ & $\mathrm{H}$ & $43 \pm 4 \%^{b}$ & & & \\
\hline 14 & $\mathrm{H}$ & $\mathrm{H}$ & $\mathrm{COOH}$ & & $\mathrm{H}$ & $39 \pm 10 \%$ b & & & \\
\hline 15 & $\mathrm{SO}_{3} \mathrm{H}$ & $\mathrm{H}$ & $\mathrm{H}$ & $\mathrm{SO}_{3} \mathrm{H}$ & $\mathrm{CH}_{3} \mathrm{CO}$ & inactive & & & \\
\hline 16 & $\mathrm{H}$ & $\mathrm{H}$ & $\mathrm{H}$ & $\mathrm{H}$ & $\mathrm{H}$ & inactive & & & inactive \\
\hline 17 & & & & & & inactive & & & inactive \\
\hline 18 & $\mathrm{SO}_{3} \mathrm{H}$ & $\mathrm{H}$ & $\mathrm{H}$ & $\mathrm{SO}_{3} \mathrm{H}$ & & $27 \pm 7 \%^{b}$ & & & $\sim 100$ \\
\hline 19 & $\mathrm{Cl}$ & $\mathrm{H}$ & $\mathrm{H}$ & $\mathrm{SO}_{3} \mathrm{H}$ & & $78 \pm 7 \%^{b}$ & & $30 \pm 10 \%^{b}$ & $\sim 100$ \\
\hline 20 & $\mathrm{H}$ & $\mathrm{H}$ & $\mathrm{H}$ & $\mathrm{H}$ & & $50 \pm 4 \%^{b}$ & & & $>100$ \\
\hline
\end{tabular}

a Inhibition of ion current (mean \pm SEM, $\mathrm{n}=4$ ), unless noted, induced by ATP (at the $\mathrm{EC}_{70}$ values in $\mu \mathrm{M}$ for respective subtypes: P2X $1, P 2 X_{2} 10$, and $P 2 X_{3} 3$ ) at recombinant $P 2 X$ receptors expressed in Xenopus oocytes (b\% inhibition at $\left.10 \mu \mathrm{M}\right)$. ${ }^{c} \mathrm{Inhibition}$ of $10 \mathrm{nM}$ 2-M eSADP-stimulated phospholipase $C$ in turkey erythrocyte membranes (mean $\pm \mathrm{SEM}, \mathrm{n}=3$ ), label ed using $\left[{ }^{3} \mathrm{H}\right]$ inositol. ${ }^{d} \mathrm{Compounds}$ reported by Kim et al. ${ }^{25}$ e Compounds and values reported by J acobson et al. ${ }^{14}$ f Compound 4, MRS 2159; compound 5, MRS 2284; compound 9, MRS 2257; compound 10, MRS 2191; compound 11, MRS 2273. 9 Compound 12 potentiates the effect of ATP at P2X receptors. ${ }^{14}$

all tested compounds on both indices of human $\mathrm{P}_{2} \mathrm{X}_{7}$ receptor activity. The apparent efficacies of the three most effective compounds $(\mathbf{2}, \mathbf{9}, \mathbf{1 0})$ as human $\mathrm{P}_{2} \mathrm{X}_{7}$ antagonists were significantly reduced in the presence of physiological divalent cation concentrations. In addition, these three compounds were significantly less potent and efficacious antagonists of the murine $\mathrm{P} 2 \mathrm{X}_{7}$ receptor even when assayed in the absence of divalent cations (data not shown). Previous studies have noted significant differences in the pharmacological antagonism of human versus rodent $\mathrm{P} 2 \mathrm{X}_{7}$ receptors. ${ }^{29}$

\section{Discussion}

Compound $\mathbf{1}$ and its analogues have been studied at a variety of $\mathrm{P} 2$ receptor subtypes. At $\mathrm{P} 2 \mathrm{Y}_{1}$ receptors, a range of potencies of $\mathbf{1}$ has been reported, from approximately $1 \mu \mathrm{M}^{30}$ to $16.6 \mu \mathrm{M}$ in the present study. Boarder and colleagues ${ }^{31}$ also showed that $\mathbf{1}$ had a curious potentiating effect at turkey $\mathrm{P}_{2} \mathrm{Y}_{1}$ receptors, which may be based on the inhibition of locally released ATP by a mechanosensory mechanism (stimulated by washing cells). Nevertheless, the potency of anal ogues of $\mathbf{2}$ prepared in the present study generally tended to be greater at $\mathrm{P} 2 \mathrm{X}_{1-3}$ subtypes than at $\mathrm{P} 2 \mathrm{Y}_{1}$ receptors. Furthermore, among the present set of analogues in which the aldehyde group remained, potencies often increased over 2 at the $\mathrm{P} 2 \mathrm{X}_{1}$ and $\mathrm{P} 2 \mathrm{X}_{3}$ subtypes and decreased at the $\mathrm{P} 2 \mathrm{X}_{7}$ receptor.

Functional group variation on the 6-(phenylazo) substituent was found to greatly modulate the potency as $\mathrm{P} 2$ receptor antagonists. For example, two analogues bearing phosphonate groups on the arylazo ring, i.e. compounds 9 and 11, were selective for "group 1" (P2X and $\mathrm{P} 2 \mathrm{X}_{3}$ receptors) versus "groups $2-4$ " $\left(\mathrm{P} 2 \mathrm{X}_{2,4,7}\right)$ receptors.

The view that $\mathbf{1}$ is an irreversible antagonist stemmed originally from pharmacokinetic data on blockade of $\mathrm{P} 2 \mathrm{X}$ receptors in whole tissues. Compound $\mathbf{1}$ was noted as having a slow on-rate (slow equilibration) and slow off-rate (slow reversibility) at native $\mathrm{P} 2 \mathrm{X}$ receptors in vascular and visceral smooth muscle (for a review, see ref 13). The fact that antagonism does eventually reverse resulted in the term "pseudo-irreversible" to describe the slow kinetics of these blocking agents. ${ }^{32}$ Nonetheless, problems associated with diffusion, surface adhesion, uptake, compartmentalization, and re-release of $\mathbf{1}$ have never been clearly resolved where whole tissue assays are employed to test their activity. Most of these problems are avoided if recombinant $\mathrm{P} 2 \mathrm{X}$ receptors are used instead, since the antagonist has direct access to the cell surface and receptor and drug concentration can be controlled by fast application and washout.

The slow onset and slow reversal of blockade by 1 at the recombinant $\mathrm{P} 2 \mathrm{X}_{1}, \mathrm{P} 2 \mathrm{X}_{2}$, and $\mathrm{P} 2 \mathrm{X}_{3}$ receptors (rat) 
A

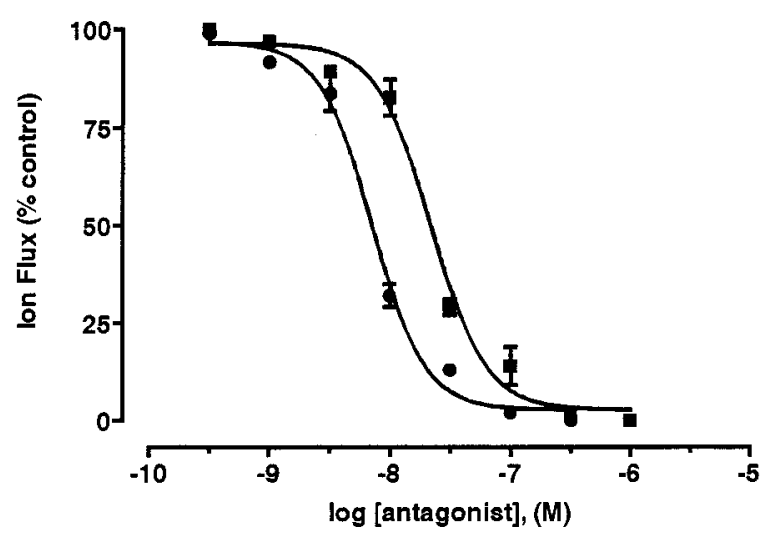

C

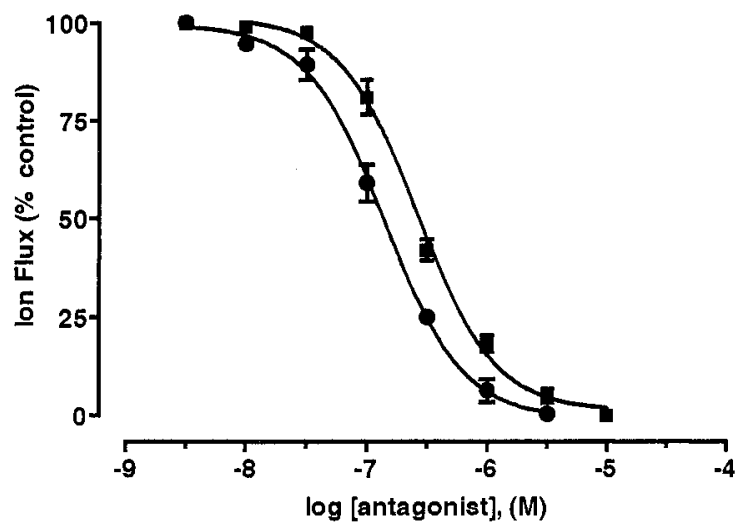

B

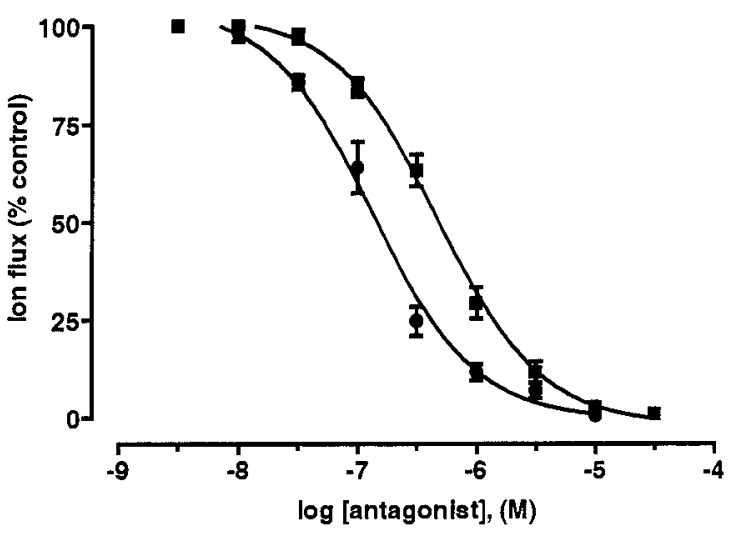

D

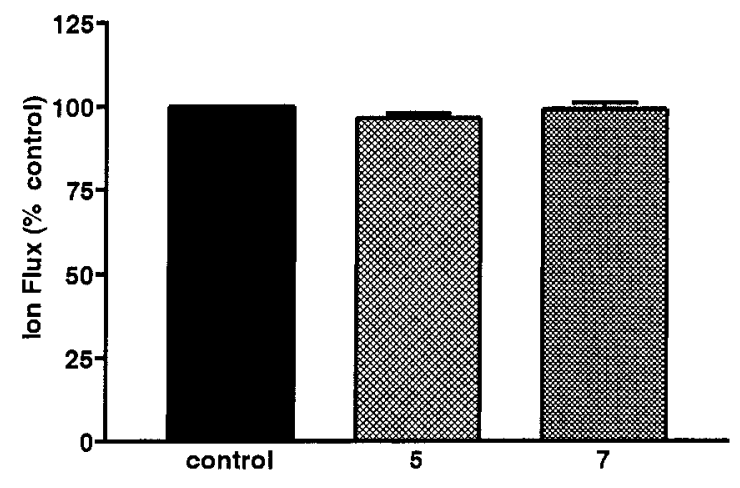

Figure 2. Potent effects of compounds $\mathbf{5}(\mathbf{0})$ and $\mathbf{7}(\mathbf{\square})$ on inward current induced by $A T P$ at recombinant rat $P 2 X_{1}(A)$ receptors and intermediate potency at rat $\mathrm{P} 2 \mathrm{X}_{2}(\mathrm{~B})$ and rat $\mathrm{P} 2 \mathrm{X}_{3}(\mathrm{C})$ receptors. Compounds $\mathbf{5}$ and $\mathbf{7}(10 \mu \mathrm{M})$ were inactive at rat $\mathrm{P} 2 \mathrm{X}_{4}(\mathrm{D})$ receptors. Receptors were expressed in Xenopus oocytes and current was measured using the twin-electrode voltage-clamping technique ( $\mathrm{pH} 7.5, \mathrm{Ba}^{2+}$ Ringer's solution). All data points were mean $\pm \mathrm{SEM}$ of 4 observations. ATP concentrations were as in Materials and Methods. IC 50 values are given in Table 2. Hill coefficients $\left(n_{H}\right)$ were: $(A)-1.20 \pm 0.07(5)$ and $-1.19 \pm 0.08(7)$; (B) $-1.11 \pm 0.009$ (5) and $-0.95 \pm 0.15$ (7); (C) $-0.87 \pm 0.04$ (5) and $-0.89 \pm 0.05$ (7).

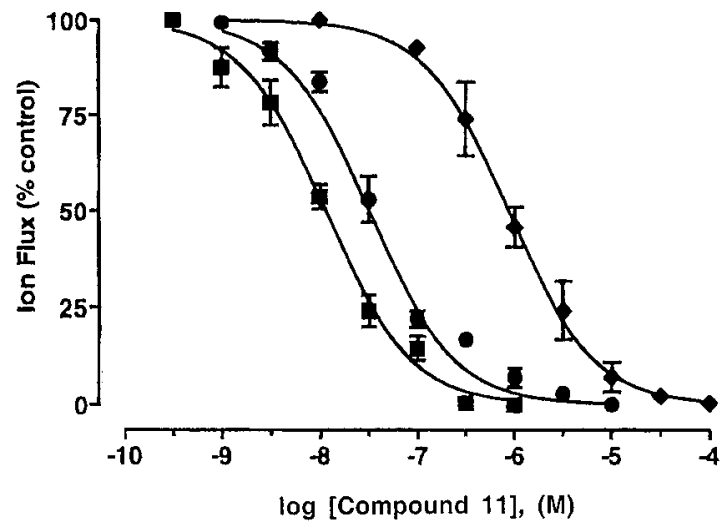

Figure 3. Selectivity of compound $\mathbf{1 1}$ on inward current induced by ATP at recombinant rat $\mathrm{P} 2 \mathrm{X}_{1}(\boldsymbol{\square})$ and rat $\mathrm{P} 2 \mathrm{X}_{3}(\bullet)$ receptors ("group 1 ") versus rat $\mathrm{P} 2 \mathrm{X}_{2}(\bullet)$ receptors ("group 2 "), expressed in Xenopus oocytes, using the twin-electrode voltageclamping technique ( $\mathrm{pH} 7.5, \mathrm{Ba}^{2+}$ Ringer's solution). All data points were mean \pm SE M of 4 observations. ATP concentrations were as in Materials and Methods. I $C_{50}$ values are given in Table 2. Hill coefficients $\left(n_{H}\right)$ were: $\left(P 2 X_{1}\right)-1.05 \pm 0.05$, $\left(\mathrm{P} 2 \mathrm{X}_{2}\right)-1.11 \pm 0.06$, and $\left(\mathrm{P} 2 \mathrm{X}_{3}\right)-1.03 \pm 0.04$.

led to the suggestion that the aldehyde group on the pyridoxal moiety formed a Schiff's base with a strategic lysyl residueat equivalent extracellular positions in P2X subunits (K249 on rP2X $1, K 246$ on rP2X $2, K 251$ on $\left.r P 2 X_{3}\right)^{33}$ However, evidence for this assumption is far from clear. Point mutation of the lysine in the $\mathrm{PP}_{2} \mathrm{X}_{2}$ subunit (K246E) did increase the rate of recovery from blockade by $\mathbf{1}$, but it did not significantly affect the potency of the antagonist. ${ }^{33}$ On the other hand, substitution of glutamate for lysine at the rat $\mathrm{P}_{2} \mathrm{X}_{4}$ subunit (E249K) increased the potency of $\mathbf{1}\left(\mathrm{IC}_{50}=>500 \mu \mathrm{M}\right.$ (wt) and $2.6 \mu \mathrm{M}$ (mutant)) yet did not noticeably accelerate recovery from blockade. ${ }^{33} \mathrm{~A}$ similar introduction of Iysine in the $\mathrm{P} 2 \mathrm{X}_{6}$ subunit ( $\mathrm{L} 251 \mathrm{~K}$ ) increased the potency of $\mathbf{1}\left(\mathrm{IC}_{50}=>500 \mu \mathrm{M}\right.$ (wt) and $2.0 \mu \mathrm{M}$ (mutant)) without affecting the rate of recovery. ${ }^{34}$

Human and mouse forms of $\mathrm{P} 2 \mathrm{X}_{4}$ do not possess a Iysine resi due at position 249 yet are significantly more sensitive to 1 ( 27.5 and $21 \mu \mathrm{M}$, respectively) than $\mathrm{rP}_{2} \mathrm{X}_{4} \cdot{ }^{35,36}$ Although sensitive to the antagonist, human and mouse $\mathrm{P} 2 \mathrm{X}_{4}$ receptors also recover very sl owly from blockade by $\mathbf{1}$. Mutation of $\mathrm{rP}_{2} \mathrm{X}_{4}$ (N 127K) to provide a Iysine unique to $\mathrm{hP} 2 \mathrm{X}_{4}$ did not enhance the sensitivity of the rat orthologue to $\mathbf{1 . 3 5}$ Furthermore, $\mathrm{mP}^{3} \mathrm{X}_{4}$ only possesses extracellular lysyl residues that are common to $\mathrm{PP}_{2} \mathrm{X}_{4},{ }^{36}$ and consequently, the heightened sensitivity to 1 of the former cannot be ascribed to a strategic Iysine. The $\mathrm{P} 2 \mathrm{X}_{3}$ subunit lacks a lysine residue at the 

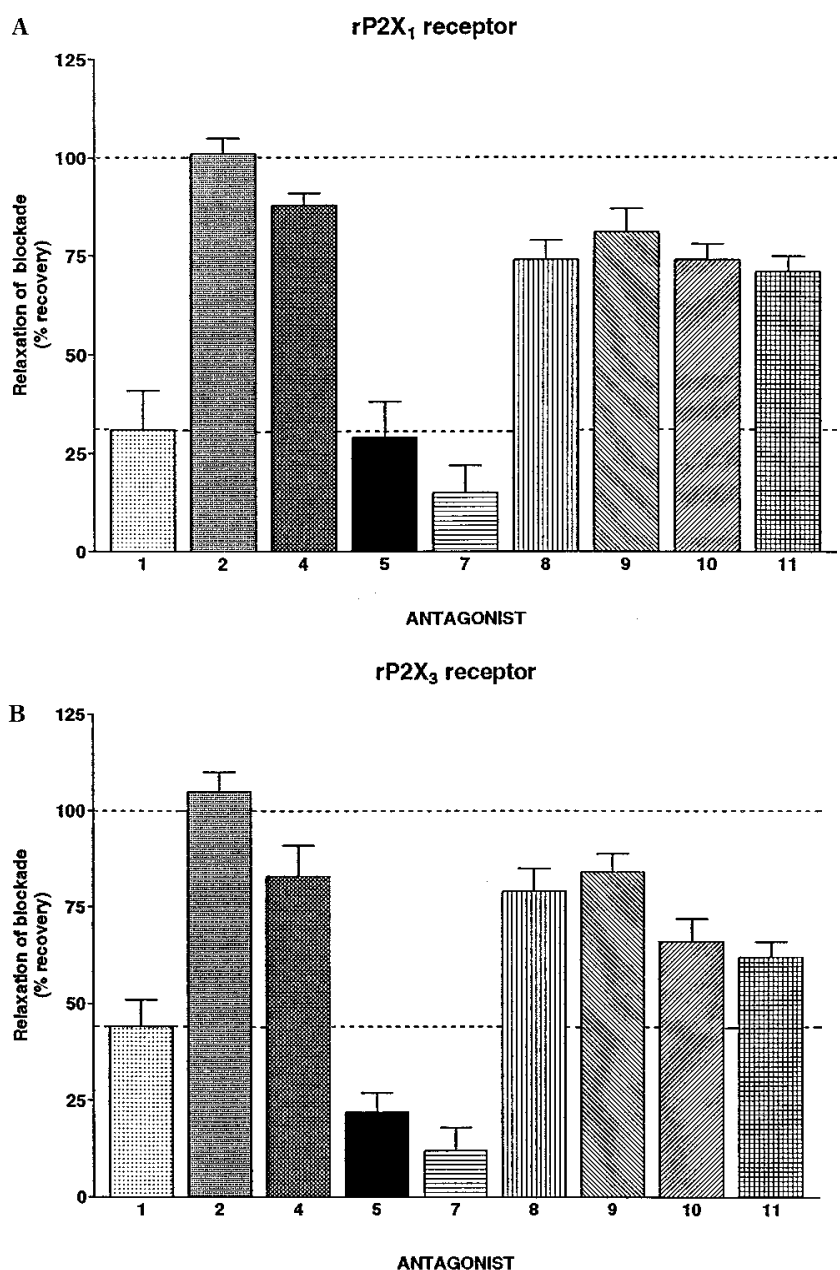

Figure 4. $\mathrm{H}$ istogram showing the degree of recovery rat $\mathrm{P} 2 \mathrm{X}_{1}$ (A) and rat $\mathrm{P} 2 \mathrm{X}_{3}(\mathrm{~B})$ receptors from full blockade by various antagonists, $20 \mathrm{~min}$ after drug washout. Compounds are indicated by their appropriate number, as shown in Table 2.

equivalent position, at which a threonine residue is found (T235), and yet $\mathbf{1}$ is potent $\left(\mathrm{IC}_{50} \sim 1 \mu \mathrm{M}\right)$ and recovery from blockade is rapid for both rat and human orthol ogues. ${ }^{35,37}$ Thus, the critical role of a strategic lysyl residue in condensation with the aldehyde of $\mathbf{1}$ is difficult to reconcile given the available data.

In the present study, the $\mathrm{C}_{50}$ value for $\mathbf{1}$ at the $\mathrm{rP} 2 \mathrm{X}_{1}$ receptor was lower than at the $\mathrm{P}_{2 \mathrm{X}}$ receptor $(0.099$ versus $0.240 \mu \mathrm{M}$; see Table 2 ), and the rate of recovery was faster at the $\mathrm{rP}_{2} \mathrm{X}_{3}$ receptor. Compound $\mathbf{2}$ proved to be more potent at both $\mathrm{rP}_{2} \mathrm{X}_{1}$ and $\mathrm{rP} 2 \mathrm{X}_{3}$ receptors, yet full recovery occurred at these receptors within 20 min of drug washout. Blockade by 2 at the $\mathrm{P} 2 \mathrm{X}_{1}$-like receptor in rat vas deferens was considered surmountable and a slow recovery reported. ${ }^{38}$ Similarly, bl ockade by 2 was reversible at $P 2 X$ receptors of rat vagus nerve bundle, 22 in which $\mathrm{P} 2 \mathrm{X}_{3}$ mRNA is present. Furthermore, it was shown that reversal of blockade by $\mathbf{1}$ at human $\mathrm{P} 2 \mathrm{X}_{3}$ receptors is accelerated by Cibacron blue which, of itself, potentiates ATP responses at this $\mathrm{P} 2 \mathrm{X}$ receptor. ${ }^{40}$ Some of the derivatives of $\mathbf{1}$ tested in the present study (e.g. compounds 4, 8-11) showed a level of recovery of about $75 \%$ and greater at $r P 2 X_{1}$ and $r P 2 X_{3}$ receptors within 20 min of washout. Thus, it now seems unnecessary to alter the aldehyde on the pyridoxal moiety, as with a pyridoxine cyclic phosphate, $3,{ }^{14}$ to make al lowances for Schiff's base formation and obtain
Table 3. Antagonistic Effects of Pyridoxal-Phosphate Derivatives on the Function of Human $\mathrm{P}_{2} \mathrm{X}_{7}$ Receptors Expressed in HEK Cells: Cation Channel Activity versus Nonselective Pore

\begin{tabular}{cccc}
\hline & \multicolumn{3}{c}{ \% inhibition of ATP-induced } \\
\cline { 2 - 4 } compd & $\begin{array}{c}\mathrm{K}^{+} \text {efflux } \\
\text { (with cations) }^{\mathrm{a}}\end{array}$ & $\begin{array}{c}\mathrm{K}^{+} \text {efflux } \\
\text { (cation-free) }^{\mathrm{b}}\end{array}$ & $\begin{array}{c}\text { ethidium } \\
\text { influx }^{\mathrm{c}}\end{array}$ \\
\hline $\mathbf{2}$ & $81 \pm 10$ & $67 \pm 14$ & $100 \pm 0$ \\
$\mathbf{9}$ & $0 \pm 3$ & $-5 \pm 3$ & $84 \pm 10$ \\
$\mathbf{1 0}$ & $51 \pm 6$ & $28 \pm 7$ & $100 \pm 0$ \\
$\mathbf{3}$ & $-1 \pm 3$ & $-5 \pm 2$ & $17 \pm 15$ \\
$\mathbf{1 8}$ & $-1 \pm 6$ & $-7 \pm 4$ & $15 \pm 15$ \\
$\mathbf{1 9}$ & $-1 \pm 5$ & $-5 \pm 3$ & $12 \pm 15$ \\
$\mathbf{2 1}^{\text {d }}$ & $14 \pm 2$ & $2 \pm 2$ & $92 \pm 15$ \\
$\mathbf{2 2}^{\text {d }}$ & $4 \pm 4$ & $1 \pm 2$ & $96 \pm 7$ \\
$\mathbf{2 3}^{\text {d }}$ & $-5 \pm 6$ & $-8 \pm 1$ & $40 \pm 35$ \\
$\mathbf{2 4}^{\text {d }}$ & $37 \pm 1$ & $24 \pm 10$ & $100 \pm 0$ \\
\hline
\end{tabular}

a Adherent HEK293 cells stably expressing the recombinant human $\mathrm{P}_{2} \mathrm{X}_{7}$ receptor; antagonist, $30 \mu \mathrm{M}$; agonist, $3 \mathrm{mM}$ ATP in divalent cation-containing medium; $n=3$. ${ }^{b}$ Adherent HEK 293 cells stably expressing the recombinant human $\mathrm{P}_{2} \mathrm{X}_{7}$ receptor; antagonist, $30 \mu \mathrm{M}$; agonist, $3 \mathrm{mM}$ ATP in divalent cation-free medium; $n=3$. ' Suspended HEK 293 cells stably expressing the recombinant human $\mathrm{P}_{2} \mathrm{X}_{7}$ receptor; antagonist, $30 \mu \mathrm{M}$; agonist, $300 \mu \mathrm{M}$ ATP in divalent cation-containing medium; $\mathrm{n}=3 .{ }^{\mathrm{d}} \mathbf{2 1}$ MRS 2157 = pyridoxal- $\alpha^{5}$-phosphate-6-azophenyl-2'-chloro-5'-sulfonic acid; 22, MRS $2160=$ pyridoxal- $\alpha^{5}$-phosphate-6-azophenyl3'-chloro-4'-carboxylic acid; 23, MRS 2192 = [4-formyl-3-hydroxy2-methyl-6-(2-chloro-5-sulfonyl phenylazo)pyrid-5-yl]methyl phosphonic acid; ${ }^{25}$ 24, MRS $2179=2^{\prime}$-deoxy- $\mathrm{N}^{6}$-methyladenosine-3', $5^{\prime}$ bisphosphate. $^{28}$

reversible antagonism at these $\mathrm{P} 2 \mathrm{X}$ receptors. Recently, a naphthyl derivative of $\mathbf{1}$ that al so retains the aldehyde group, pyridoxal- $\alpha^{5}$-phosphate-6-(2'-naphthylazo-6'-nitro-4', $8^{\prime}$-disulfonic acid), was shown to be a potent selective and reversible antagonist of $\mathrm{P}_{2} \mathrm{X}_{1}$ receptors. ${ }^{39}$

Some $\mathrm{P} 2$ receptor antagonists also may inhibit ectonucleotidases, making these studies even more complex. We are currently studying ecto-nucleotidase inhibition by selected analogues of $\mathbf{2} .^{41}$ Preliminary results with the recombinant enzymes expressed in $\mathrm{CHO}$ cells indicate that most of the analogues of $\mathbf{1}$ were better inhibitors of ecto-apyrase than of ecto-ATPase. The aldehyde group appears to be required for ecto-apyrase inhibition. However, the efficacy of derivatives of $\mathbf{1}$ as inhibitors of ecto-enzymes had no bearing on their efficacy as antagonists at $\mathrm{P}_{2} \mathrm{X}_{1-3}$ receptors expressed in Xenopus oocytes, since defolliculated oocytes are largely devoid of surface enzymes that degrade ATP. 42

In conclusion, we have identified highly potent and selective antagonists of $\mathrm{P}_{2} \mathrm{X}_{1}$ receptors and antagonists of combined $\mathrm{P} 2 \mathrm{X}_{1,3}$ receptor sel ectivity. Damer et al. ${ }^{43}$ have al so reported an antagonist with high affinity and apparent $\mathrm{P} 2 \mathrm{X}_{1}$ receptor selectivity: the suramin analogue NF 279 (8,8'-(carbonyl bis(imino-4,1-phenylenecarbonylimino-4,1-phenylenecarbonylimino))bis(1,3,5-naphthalenetrisulfonic acid). A selective $\mathrm{P} 2 \mathrm{X}_{1}$ receptor antagonist may have potential utility in controlling receptor-mediated contraction of visceral and vascular smooth muscle (e.g. vascular hypertension and instability of the urinary bladder detrusor muscle). A selective $\mathrm{P}_{2} \mathrm{X}_{3}$ receptor antagonist may be useful in pain control. The properties of selective $\mathrm{P} 2$ receptor antagonists in the central nervous system remain to be examined.

\section{Materials and Methods}

Synthesis. Materials and Analytical Methods. Compounds 4, 6, 8, 10 and (4-formyl-3-hydroxy-2-methyl-5-pyridyl)- 
methylphosphonic acid, as the starting compound for the synthesis of compounds 5, 7, and 9-11, were prepared as described in a previous report. ${ }^{25}$ Compounds $\mathbf{3}$ and $\mathbf{1 2}$ were synthesized according to the literature. ${ }^{14}$ Pyridoxine and the reagents for azo coupling reactions were purchased from Aldrich (St. Louis, MO). Aniline-2,5-disulfonic acid was obtained from K \& K Laboratories, Inc. (Hollywood, CA).

${ }^{1} \mathrm{H}$ NMR spectroscopy was performed on a Varian GEMI NI300 spectrometer and spectra were taken in $\mathrm{D}_{2} \mathrm{O}$ or $\mathrm{CDCl}_{3}$. The chemical shifts are expressed as relative ppm from $\mathrm{HOD}$ peaks $(4.78 \mathrm{ppm})$ or as ppm downfield from tetramethylsilane. 31P NMR spectra were recorded without proton decoupling mode, at room temperature using a Varian XL-300 spectrometer (121.419 MHz); orthophosphoric acid (85\%) was used as an external standard. High-resolution mass spectroscopy (HRMS) using FAB (fast atom bombardment) or EI (electron impact) was determined with a J EOL SX102 spectrometer, and electron spray mass spectra were obtained using a HewlettPackard 1100 LC-ESPRAY system.

The determinations of purity were performed with a HewlettPackard 1090 HPLC system using an OD-5-60 C18 analytical column $(250 \mathrm{~mm} \times 4.6 \mathrm{~mm}$; Separation Methods Technol ogies, Inc., Newark, DE) in two different linear gradient solvent systems. One solvent system (A) was $0.1 \mathrm{M}$ triethylammonium acetate buffer: $\mathrm{CH}_{3} \mathrm{CN}=95: 5$ to $40: 60$ for 20 min with flow rate $=1 \mathrm{~mL} / \mathrm{min}$. The other $(B)$ was $5 \mathrm{mM}$ tetrabutylammonium phosphate buffer: $\mathrm{CH}_{3} \mathrm{CN}=80: 20$ to $40: 60$ in 20 min with flow rate $=1 \mathrm{~mL} / \mathrm{min}$. Peaks were detected by UV absorption using a diode array detector.

General Procedure A for Azo Coupling Reactions. To a stirred solution of an aniline analogue $(0.11 \mathrm{mmol})$ and 13 $\mathrm{mg}(0.12 \mathrm{mmol})$ of $\mathrm{Na}_{2} \mathrm{CO}_{3}$ in $1 \mathrm{~mL}$ of $\mathrm{H}_{2} \mathrm{O}$ was added $8 \mathrm{mg}$ $(0.12 \mathrm{mmol})$ of $\mathrm{NaNO}_{2}$ at $0{ }^{\circ} \mathrm{C} .60 \mu \mathrm{L}(0.36 \mathrm{mmol})$ of $6 \mathrm{~N} \mathrm{HCl}$ was added dropwise, and the mixture was stirred for 5-10 min at $0{ }^{\circ} \mathrm{C}$. A solution of a pyridoxal-or pyridoxine-phosphate analogue $(0.1 \mathrm{mmol})$ in $1 \mathrm{~mL}$ of $\mathrm{H}_{2} \mathrm{O}$ was added at once, and the $\mathrm{pH}$ of the mixture was adjusted to $10-11$ by addition of 1 $\mathrm{N} \mathrm{NaOH}(\sim 300 \mu \mathrm{L})$. The yellow color changed to red (sometimes gradually) as an indicator of the reaction occurring. After stirring for $30 \mathrm{~min}$ at $0{ }^{\circ} \mathrm{C}$ and $30 \mathrm{~min}$ at $25^{\circ} \mathrm{C}$, the mixture was purified by ion-exchange column chromatography using Amberlite CG-50 resin ( $\mathrm{H}^{+}$form, weakly acidic) with the elution of water (flow rate $0.5 \mathrm{~mL} / \mathrm{min}$ ). The red fraction showing a single peak in HPLC was collected and lyophilized to give the desired compound with more than 95\% purity.

[4-Formyl-3-hydroxy-2-methyl-6-(4'-carboxyphenylazo)pyrid-5-yl]methylphosphonic Acid Disodium Salt (5). Following the general procedure A with $23 \mathrm{mg}(0.1 \mathrm{mmol})$ of (4-formyl-3-hydroxy-2-methyl-5-pyridyl)methyl phosphonic acid and $16 \mathrm{mg}(0.12 \mathrm{mmol})$ of 4-aminobenzoic acid, $27 \mathrm{mg}$ of 5 was obtained (yield $71 \%)$ : ${ }^{1} \mathrm{H}$ NMR $\left(\mathrm{D}_{2} \mathrm{O}\right) \delta 2.41\left(3 \mathrm{H}, \mathrm{s},-\mathrm{CH}_{3}\right)$ $3.85\left(2 \mathrm{H}, \mathrm{d}, \mathrm{J}=21.5 \mathrm{~Hz},-\mathrm{CH}_{2} \mathrm{P}-\right), 7.70(2 \mathrm{H}, \mathrm{d}, \mathrm{J}=7.8 \mathrm{~Hz}$, phenyl), $7.88(2 \mathrm{H}, \mathrm{d}, \mathrm{J}=7.8 \mathrm{~Hz}$, phenyl), $10.24(1 \mathrm{H}, \mathrm{s},-\mathrm{CHO}$; ${ }^{31} \mathrm{P}$ NMR $\left(\mathrm{D}_{2} \mathrm{O}\right) \delta-4.61(\mathrm{t}, \mathrm{J}=21.4 \mathrm{~Hz})$.

[4-F ormyl-3-hydroxy-2-methyl-6-(2, 5'-dicarboxyphenylazo)pyrid-5-yl]methylphosphonic Acid Disodium Salt (7). Following the general procedure A with $23 \mathrm{mg}(0.115$ $\mathrm{mmol}$ ) of (4-formyl-3-hydroxy-2-methyl-5-pyridyl)methylphosphonic acid and $22 \mathrm{mg}(0.12 \mathrm{mmol})$ of 2-aminoterephthalic acid, $25 \mathrm{mg}$ of 7 was obtained (yield 59\%): ${ }^{1} \mathrm{H}$ NMR $\left(\mathrm{D}_{2} \mathrm{O}\right) \delta 2.01$ $\left(3 \mathrm{H}, \mathrm{s},-\mathrm{CH}_{3}\right), 3.77\left(2 \mathrm{H}, \mathrm{d}, \mathrm{J}=21.5 \mathrm{~Hz},-\mathrm{CH}_{2} \mathrm{P}-\right), 7.48(1 \mathrm{H}$, $\mathrm{d}, \mathrm{J}=7.8 \mathrm{~Hz}$, phenyl ), $7.74(1 \mathrm{H}, \mathrm{d}, \mathrm{J}=7.8 \mathrm{~Hz}$, phenyl), 8.01 $(1 \mathrm{H}, \mathrm{s}$, phenyl $), 10.09(1 \mathrm{H}, \mathrm{s},-\mathrm{CHO}) ;{ }^{31} \mathrm{P}$ NMR $\left(\mathrm{D}_{2} \mathrm{O}\right) \delta-4.31$ $(\mathrm{t}, \mathrm{J}=21.5 \mathrm{~Hz}$ ).

[4-F ormyl-3-hydroxy-2-methyl-6-azo(3',5'-bismethylphosphonylphenyl)-5-pyridyl]methylphosphonic Acid Disodium Salt (9). Following the general procedure A with $46 \mathrm{mg}$ (0.2 mmol) of (4-formyl-3-hydroxy-2-methyl-5-pyridyl)methylphosphonic acid and $56 \mathrm{mg}(0.2 \mathrm{mmol})$ of 1-aminobenzene-3,5-bis(methylphosphonic acid), $24 \mathrm{mg}$ of 9 was obtained (yield $21 \%)$ : ${ }^{1} \mathrm{H}$ NMR $\left(\mathrm{D}_{2} \mathrm{O}\right) \delta 2.54\left(3 \mathrm{H}, \mathrm{s},-\mathrm{CH}_{3}\right)$, $3.19\left(4 \mathrm{H}, \mathrm{d}, \mathrm{J}=21.5 \mathrm{~Hz}, 2 \times-\mathrm{CH}_{2} \mathrm{P}-\right), 4.05(2 \mathrm{H}, \mathrm{d}, \mathrm{J}=21.5$ $\left.\mathrm{Hz},-\mathrm{CH}_{2} \mathrm{P}-\right), 7.39(1 \mathrm{H}, \mathrm{s}$, phenyl), $7.76(2 \mathrm{H}, \mathrm{s}$, phenyl), 10.36
$(1 \mathrm{H}, \mathrm{s},-\mathrm{CHO}) ;{ }^{31} \mathrm{P}$ NMR $\left(\mathrm{D}_{2} \mathrm{O}\right) \delta 17.89(\mathrm{t}, \mathrm{J}=20.9 \mathrm{~Hz}), 21.69$ (m), $22.29(\mathrm{~m})$

[4-F ormyl-3-hydroxy-2-methyl-6-(4'-phosphonylphenylazo)pyrid-5-yl]methylphosphonic Acid Disodium Salt (11). Following the general procedure A with $23 \mathrm{mg}(0.115$ $\mathrm{mmol}$ ) of (4-formyl-3-hydroxy-2-methyl-5-pyridyl)methyl phosphonic acid and $20 \mathrm{mg}(0.115 \mathrm{mmol})$ of $\mathbf{2 9}, 36 \mathrm{mg}$ of $\mathbf{1 1}$ was obtained (yield 68\%): ${ }^{1} \mathrm{H}$ NMR $\left(\mathrm{D}_{2} \mathrm{O}\right) \delta 2.48\left(3 \mathrm{H}, \mathrm{s},-\mathrm{CH}_{3}\right)$, $3.99\left(2 \mathrm{H}, \mathrm{d}, \mathrm{J}=21.5 \mathrm{~Hz},-\mathrm{CH}_{2} \mathrm{P}-\right), 7.82-7.89(4 \mathrm{H}, \mathrm{m}$, phenyl), $10.27(1 \mathrm{H}, \mathrm{s},-\mathrm{CHO}) ;{ }^{31} \mathrm{P} N M R\left(\mathrm{D}_{2} \mathrm{O}\right) \delta 12.83(\mathrm{~m}), 17.89(\mathrm{t}, \mathrm{J}$ $=21.4 \mathrm{~Hz})$.

Pyridoxine- $\alpha^{4,5}$-cyclomonophosphate-6-azophenyl-2 chloro-5'-sulfonic Acid Monosodium Salt (13). Following the general procedure A with $0.1 \mathrm{~g}(0.432 \mathrm{mmol})$ of $\mathbf{1 2}$ and $0.11 \mathrm{~g}(0.444 \mathrm{mmol})$ of aniline-2-chloro-5-sulfonic acid, $0.12 \mathrm{~g}$ of 5 was obtained (yield 59\%): ${ }^{1} \mathrm{H} N M R\left(\mathrm{D}_{2} \mathrm{O}\right) \delta 2.47(3 \mathrm{H}, \mathrm{s}$, $\left.-\mathrm{CH}_{3}\right), 5.18\left(2 \mathrm{H}, \mathrm{d}, \mathrm{J}=15.6 \mathrm{~Hz},-\mathrm{CH}_{2} \mathrm{O}-\right), 5.61(2 \mathrm{H}, \mathrm{d}, \mathrm{J}=$ $\left.15.6 \mathrm{~Hz},-\mathrm{CH}_{2} \mathrm{O}-\right), 7.56(1 \mathrm{H}, \mathrm{d}, \mathrm{J}=8.8 \mathrm{~Hz}$, phenyl), $7.67(1 \mathrm{H}$, $\mathrm{d}, \mathrm{J}=8.8 \mathrm{~Hz}$, phenyl), $7.95\left(1 \mathrm{H}, \mathrm{s}\right.$, phenyl); ${ }^{31} \mathrm{P} \mathrm{NMR}\left(\mathrm{D}_{2} \mathrm{O}\right) \delta$ 5.48 (pen, J $=15.9 \mathrm{~Hz}$ ).

Pyridoxine- $\alpha^{4,5}$-cyclomonophosphate-6-azophenyl-4'carboxylic Acid (14). Following the general procedure $A$ with $50 \mathrm{mg}(0.216 \mathrm{mmol})$ of $\mathbf{1 2}$ and $0.03 \mathrm{~g}(0.216 \mathrm{mmol})$ of 4-aminobenzoic acid, $35 \mathrm{mg}$ of $\mathbf{1 4}$ was obtained (yield $43 \%$ ): ${ }^{1} \mathrm{H} N M R\left(\mathrm{D}_{2} \mathrm{O}\right) \delta 2.32\left(3 \mathrm{H}, \mathrm{s},-\mathrm{CH}_{3}\right), 5.00(2 \mathrm{H}, \mathrm{d}, \mathrm{J}=15.6 \mathrm{~Hz}$ $\left.-\mathrm{CH}_{2} \mathrm{O}-\right), 5.47\left(2 \mathrm{H}, \mathrm{d}, \mathrm{J}=15.6 \mathrm{~Hz},-\mathrm{CH}_{2} \mathrm{O}-\right), 7.58(2 \mathrm{H}, \mathrm{d}$, J $=7.8 \mathrm{~Hz}$, phenyl $), 7.81\left(2 \mathrm{H}, \mathrm{d}, \mathrm{J}=8.8 \mathrm{~Hz}\right.$, phenyl); ${ }^{31} \mathrm{P} N M \mathrm{R}$ $\left(\mathrm{D}_{2} \mathrm{O}\right) \delta 5.50$ (pen, J $=15.9 \mathrm{~Hz}$ ).

$0^{3}$-Acetylpyridoxi ne- $\alpha^{4,5}$-cyclomonophosphate-6azophenyl-2',5'-disulfonic Acid Monotriethylamine Disodium Salt (15). A mixture of $23 \mathrm{mg}(0.043 \mathrm{mmol})$ of 3, 100 $\mu \mathrm{L}$ of acetic anhydride and $100 \mu \mathrm{L}$ of triethylamine in $1 \mathrm{~mL}$ of DMF was stirred for $1 \mathrm{~h}$. The reaction mixture was purified with the same ion-exchange column chromatography in general procedure A to give $27 \mathrm{mg}$ of $\mathbf{1 5}$ (100\% yield): ${ }^{1} \mathrm{H}$ NMR $\left(\mathrm{D}_{2} \mathrm{O}\right) \delta 1.23\left(9 \mathrm{H}, \mathrm{t}, \mathrm{J}=6.8 \mathrm{~Hz}, 3 \times-\mathrm{CH}_{3}\right), 2.42\left(3 \mathrm{H}, \mathrm{s},-\mathrm{CH}_{3}\right)$ $2.49\left(3 \mathrm{H}, \mathrm{s},-\mathrm{CH}_{3}\right), 3.15\left(6 \mathrm{H}, \mathrm{q}, \mathrm{J}=6.8 \mathrm{~Hz}, 3 \times-\mathrm{CH}_{2}\right), 5.18$ $\left(2 \mathrm{H}, \mathrm{d}, \mathrm{J}=15.6 \mathrm{~Hz},-\mathrm{CH}_{2} \mathrm{O}-\right), 5.71(2 \mathrm{H}, \mathrm{d}, \mathrm{J}=15.6 \mathrm{~Hz}$, $\left.-\mathrm{CH}_{2} \mathrm{O}-\right), 7.91(1 \mathrm{H}, \mathrm{s}$, phenyl), $8.05(1 \mathrm{H}, \mathrm{d}, \mathrm{J}=7.8 \mathrm{~Hz}$, phenyl), $8.18\left(1 \mathrm{H}, \mathrm{d}, \mathrm{J}=7.8 \mathrm{~Hz}\right.$, phenyl); ${ }^{31} \mathrm{P} \mathrm{NMR}\left(\mathrm{D}_{2} \mathrm{O}\right) \delta$ 5.08 (pen, J $=15.9 \mathrm{~Hz}$ ).

Pyridoxine-6-azophenyl- $\alpha^{4,5}$-cyclomonophosphoric Acid Monosodium Salt (16). Following the general procedure A with $25 \mathrm{mg}(0.108 \mathrm{mmol})$ of 12 and $24 \mathrm{mg}(0.189 \mathrm{mmol})$ of aniline hydrochloride, $10 \mathrm{mg}$ of $\mathbf{1 6}$ was obtained (yield 28\%): ${ }^{1} \mathrm{H}$ NMR $\left(\mathrm{D}_{2} \mathrm{O}\right) \delta 2.34\left(3 \mathrm{H}, \mathrm{s},-\mathrm{CH}_{3}\right), 5.05(2 \mathrm{H}, \mathrm{d}$, J $=15.6 \mathrm{~Hz}$, $\left.-\mathrm{CH}_{2} \mathrm{O}-\right), 5.49\left(2 \mathrm{H}, \mathrm{d}, \mathrm{J}=15.6 \mathrm{~Hz},-\mathrm{CH}_{2} \mathrm{O}-\right), 7.37-7.39(3 \mathrm{H}$, $\mathrm{m}$, phenyl), 7.59-7.62 (2H, m, phenyl); ${ }^{31} \mathrm{P} N \mathrm{NMR}\left(\mathrm{D}_{2} \mathrm{O}\right) \delta 5.30$ (pen, J = 15.9 Hz); HRMS (FAB-) calcd 334.0593, found 334.0607. HPLC retention time 7.2 min (purity >98\%).

Pyridoxine- $\alpha^{4,5}$-bisphosphate Tetraammonium Salt (17). To a suspension of $0.5 \mathrm{~g}(2.96 \mathrm{mmol})$ of pyridoxine in 2.5 $\mathrm{mL}$ of anhydrous benzene was added $5 \mathrm{~mL}$ of trimethylsilyl polyphosphate under nitrogen atmosphere. The mixture was stirred at $85^{\circ} \mathrm{C}$ for 2 days and poured into $30 \mathrm{~mL}$ of anhydrous ether. The white precipitate was collected by filtration, washed with anhydrous ether, and dissolved in $30 \mathrm{~mL}$ of water. The water solution was stirred at $70{ }^{\circ} \mathrm{C}$ for $12 \mathrm{~h}$ to cleave multiphosphate groups and remove trimethylsilyl group, and passed through Amberlite CG-50 resin $\left(\mathrm{H}^{+}\right.$form, weakly acidic) with the elution of water (flow rate $0.5 \mathrm{~mL} / \mathrm{min}$ ). The acidic fractions with UV absorption were combined, lyophillized, redissolved $10 \mathrm{~mL}$ of water, and neutralized by triethylamine $(\mathrm{pH} \sim 7)$. The desired product was purified using Sephadex-DEAE A-25 $\left(\mathrm{HCO}_{3}{ }^{-}\right.$form) ion-exchange column chromatography with a linear gradient elution of water and $0.5 \mathrm{M}$ ammonium bicarbonate solution. The pure fractions determined by HPLC were collected and repeated lyophilization with water gave $0.215 \mathrm{~g}$ of $\mathbf{1 7}$ (yield $18 \%)$ : ${ }^{1} \mathrm{H}$ NMR $\left(\mathrm{D}_{2} \mathrm{O}\right)$ $\delta 2.43\left(3 \mathrm{H}, \mathrm{s},-\mathrm{CH}_{3}\right), 4.92\left(2 \mathrm{H}, \mathrm{s},-\mathrm{CH}_{2} \mathrm{O}-\right), 4.94(2 \mathrm{H}, \mathrm{d}, \mathrm{J}=$ $\left.2.9 \mathrm{~Hz},-\mathrm{CH}_{2} \mathrm{O}-\right)$, $7.86(1 \mathrm{H}, \mathrm{s}, \mathrm{H}-6)$; ${ }^{31} \mathrm{P}$ NMR $\left(\mathrm{D}_{2} \mathrm{O}\right) \delta 3.51$ (t, $\mathrm{J}=5.5 \mathrm{~Hz}), 4.40(\mathrm{pt})$.

Pyridoxine- $\alpha^{4,5}$-bisphosphate-6-azophenyl-2 , 5' -disulfonic Acid Disodium Salt (18). Following the general 
procedure A with $25 \mathrm{mg}(0.063 \mathrm{mmol})$ of 17 and $16 \mathrm{mg}(0.063$ mmol) of aniline-2,5-disulfonic acid, $32 \mathrm{mg}$ of $\mathbf{1 8}$ was obtained (yield 80\%): ${ }^{1} \mathrm{H} N M R\left(\mathrm{D}_{2} \mathrm{O}\right) \delta 2.72\left(3 \mathrm{H}, \mathrm{s},-\mathrm{CH}_{3}\right), 5.32(2 \mathrm{H}, \mathrm{d}$, $\left.\mathrm{J}=8.8 \mathrm{~Hz},-\mathrm{CH}_{2} \mathrm{O}-\right), 5.68\left(2 \mathrm{H}, \mathrm{d}, \mathrm{J}=6.8 \mathrm{~Hz},-\mathrm{CH}_{2} \mathrm{O}-\right)$, $8.04(1 \mathrm{H}, \mathrm{d}, \mathrm{J}=7.8 \mathrm{~Hz}$, phenyl), $8.13(1 \mathrm{H}, \mathrm{s}$, phenyl), 8.18 $\left(1 \mathrm{H}, \mathrm{d}, \mathrm{J}=7.8 \mathrm{~Hz}\right.$, phenyl); ${ }^{31} \mathrm{P} \mathrm{NMR}\left(\mathrm{D}_{2} \mathrm{O}\right) \delta-0.06(\mathrm{t}, \mathrm{J}=$ $6.8 \mathrm{~Hz}), 1.67$ (pt).

Pyridoxine- $\alpha^{4,5}$-bisphosphate-6-azophenyl-2'-chloro-5' sulfonic Acid Monosodium Salt (19). Following the general procedure A with $25 \mathrm{mg}(0.063 \mathrm{mmol})$ of 17 and $16 \mathrm{mg}(0.063$ mmol) of aniline-2-chloro-5-sulfonic acid, $26 \mathrm{mg}$ of 19 was obtained (yield 73\%): ${ }^{1} \mathrm{H}$ NMR $\left(\mathrm{D}_{2} \mathrm{O}\right) \delta 2.68\left(3 \mathrm{H}, \mathrm{s},-\mathrm{CH}_{3}\right)$, $5.31\left(2 \mathrm{H}, \mathrm{d}, \mathrm{J}=8.8 \mathrm{~Hz},-\mathrm{CH}_{2} \mathrm{O}-\right), 5.67(2 \mathrm{H}, \mathrm{d}, \mathrm{J}=6.8 \mathrm{~Hz}$, $\left.-\mathrm{CH}_{2} \mathrm{O}-\right), 7.79(1 \mathrm{H}, \mathrm{d}, \mathrm{J}=7.8 \mathrm{~Hz}$, phenyl $), 7.92(1 \mathrm{H}, \mathrm{dd}, \mathrm{J}=$ 2.0, 7.8 Hz, phenyl), $8.18\left(1 \mathrm{H}, \mathrm{d}, \mathrm{J}=2.0 \mathrm{~Hz}\right.$, phenyl); ${ }^{31} \mathrm{P} \mathrm{NMR}$ $\left(\mathrm{D}_{2} \mathrm{O}\right) \delta-0.06(\mathrm{t}, \mathrm{J}=6.2 \mathrm{~Hz}), 1.69(\mathrm{pt})$.

Pyridoxine-6-azophenyl- $\alpha^{4,5}$-bisphosphoric Acid Monosodium Salt (20). Following the general procedure $A$ with $25 \mathrm{mg}(0.063 \mathrm{mmol})$ of 17 and $24 \mathrm{mg}(0.189 \mathrm{mmol})$ of aniline hydrochloride, 22 mg of $\mathbf{2 0}$ was obtained (yield $81 \%$ ): ${ }^{1} \mathrm{H}$ NMR $\left(\mathrm{D}_{2} \mathrm{O}\right) \delta 2.54\left(3 \mathrm{H}, \mathrm{s},-\mathrm{CH}_{3}\right), 5.20\left(2 \mathrm{H}, \mathrm{d}, \mathrm{J}=7.8 \mathrm{~Hz},-\mathrm{CH}_{2} \mathrm{O}-\right.$ ), $5.55\left(2 \mathrm{H}, \mathrm{d}, \mathrm{J}=4.9 \mathrm{~Hz},-\mathrm{CH}_{2} \mathrm{O}-\right), 7.57-7.59(3 \mathrm{H}, \mathrm{m}$, phenyl), 7.93-7.96 (2H, m, phenyl); ${ }^{31} \mathrm{P}$ NMR $\left(\mathrm{D}_{2} \mathrm{O}\right) \delta 0.08(\mathrm{t}$, $\mathrm{J}=5.2 \mathrm{~Hz}), 1.54(\mathrm{t}, \mathrm{J}=7.9 \mathrm{~Hz})$.

3,5-Bis(bromomethyl)-1-nitrobenzene (25). A solution of $1.89 \mathrm{~g}$ of 5-nitro-m-xylene-( $\left.\alpha, \alpha^{\prime}\right)$-diol (10 mmol), $5.25 \mathrm{~g}$ of triphenylphosphine ( $20 \mathrm{mmol})$, and $6.62 \mathrm{~g}$ of carbon tetrabromide $(20 \mathrm{mmol})$ in $50 \mathrm{~mL}$ of anhydrous ether was stirred at $25{ }^{\circ} \mathrm{C}$ for $12 \mathrm{~h}$ under $\mathrm{N}_{2}$ atmosphere. After evaporation, the residue was purified with flash silica gel column chromatography (Hex/EtOAC $=5 / 1)$ to give $1.6 \mathrm{~g}$ of $\mathbf{2 5}$ as a bright yellow solid (52\%): ${ }^{1} \mathrm{H} N M R\left(\mathrm{CDCl}_{3}\right) \delta 4.53\left(4 \mathrm{H}, \mathrm{s}, 2 \times-\mathrm{CH}_{2} \mathrm{Br}\right), 6.83$ (1H, S, Ph), $7.76(1 \mathrm{H}, \mathrm{S}, \mathrm{Ph}), 8.20(1 \mathrm{H}, \mathrm{S}, \mathrm{Ph}) ; \mathrm{MS}(\mathrm{EI})\left(\mathrm{M}^{+}\right)$ 309; HRMS (EI) calcd 306.8843, found 306.8859.

Tetramethyl 1-Aminobenzene-3,5-bis(methylphosphonate) (26). A solution of $1.4 \mathrm{~g}$ of $25(4.53 \mathrm{mmol})$ in $15 \mathrm{~mL}$ of trimethyl phosphite was heated at $80^{\circ} \mathrm{C}$ for $6 \mathrm{~h}$. After evaporation, the residue was purified with flash silica gel column chromatography $\left(\mathrm{CHCl}_{3} / \mathrm{MeOH}=30 / 1\right)$ to give $1.57 \mathrm{~g}$ of tetramethyl 1-nitrobenzene-3,5-bis(methylphosphonate) as a white solid (94\%): ${ }^{1} \mathrm{H}$ NMR $\left(\mathrm{CDCl}_{3}\right) \delta 3.25(4 \mathrm{H}, \mathrm{d}, \mathrm{J}=21.5$ $\left.\mathrm{Hz}, 2 \times-\mathrm{CH}_{2} \mathrm{P}-\right), 3.72\left(3 \mathrm{H}, \mathrm{s},-\mathrm{CH}_{3}\right), 3.73\left(3 \mathrm{H}, \mathrm{s},-\mathrm{CH}_{3}\right), 3.75$ $\left(3 \mathrm{H}, \mathrm{s},-\mathrm{CH}_{3}\right), 3.76\left(3 \mathrm{H}, \mathrm{s},-\mathrm{CH}_{3}\right), 7.28(1 \mathrm{H}, \mathrm{s}, \mathrm{Ph}), 7.60(1 \mathrm{H}$, $\mathrm{s}, \mathrm{Ph}), 8.06(1 \mathrm{H}, \mathrm{s}, \mathrm{Ph}) ;{ }^{31} \mathrm{P} \mathrm{NMR}\left(\mathrm{CDCl}_{3}\right) \delta 27.09(\mathrm{~m}), 33.48$ (m); MS (EI) $\left(\mathrm{M}^{+}\right) 367$ HRMS (EI) calcd 367.0586, found 367.0592 .

A solution of $40 \mathrm{mg}$ of tetramethyl 1-nitrobenzene-3,5-bis(methylphosphonate) $(4.53 \mathrm{mmol}$ ) and $10 \mathrm{mg}$ of $10 \% \mathrm{Pd} / \mathrm{C}$ in $3 \mathrm{~mL}$ of methanol was stirred at $25{ }^{\circ} \mathrm{C}$ for $1 \mathrm{~h}$ under $\mathrm{H}_{2}$ atmosphere. The mixture was filtered through a Celite bed and purified with preparative thin-layer chromatography $\left(\mathrm{CHCl}_{3} / \mathrm{MeOH}=20 / 1\right)$ to give $37 \mathrm{mg}$ of $\mathbf{2 6}$ as a white solid (100\%): ${ }^{1} \mathrm{H} \mathrm{NMR}\left(\mathrm{CDCl}_{3}\right) \delta 3.06(4 \mathrm{H}, \mathrm{d}, \mathrm{J}=21.5 \mathrm{~Hz}, 2 \times$ $\left.-\mathrm{CH}_{2} \mathrm{P}-\right), 3.66\left(6 \mathrm{H}, \mathrm{s}, 2 \times-\mathrm{CH}_{3}\right), 3.70\left(6 \mathrm{H}, \mathrm{s}, 2 \times-\mathrm{CH}_{3}\right), 6.55$ $(2 \mathrm{H}, \mathrm{s}, \mathrm{Ph}), 6.59(1 \mathrm{H}, \mathrm{s}, \mathrm{Ph}) ;{ }^{31} \mathrm{P} \mathrm{NMR}\left(\mathrm{CDCl}_{3}\right) \delta 27.09(\mathrm{~m})$, $33.48(\mathrm{~m})$ : with proton decoupling off mode; $\mathrm{MS}(\mathrm{EI})\left(\mathrm{M}^{+}\right) 337$; HRMS (EI) calcd 337.0844, found 337.0845.

1-Aminobenzene-3,5-bis(methylphosphonic acid) Tetraammonium Salt (27). To a solution of $35 \mathrm{mg}$ of $\mathbf{2 6}(0.10$ mmol) in $2 \mathrm{~mL}$ of anhydrous $\mathrm{CH}_{3} \mathrm{CN}$ was added $0.14 \mathrm{~mL}$ of trimethylsilyl bromide $(1.04 \mathrm{mmol})$ at $25^{\circ} \mathrm{C}$ under $\mathrm{N}_{2}$ atmosphere. The mixture was stirred for $12 \mathrm{~h}$, and the solvent was removed by $\mathrm{N}_{2}$ stream. The residue was partitioned between diethyl ether and $0.5 \mathrm{M}$ ammonium bicarbonate solution. The aqueous fraction was applied to an ion-exchange chromatography column (Sephadex-DEAE A-25 resin) and eluted with a linear gradient $(0.01$ to $0.5 \mathrm{M}$ ) of $0.5 \mathrm{M}$ ammonium bicarbonate. UV and HPLC were used to monitor the elution to give $35 \mathrm{mg}$ of 27 (100\%): ${ }^{1} \mathrm{H}$ NMR $\left(\mathrm{D}_{2} \mathrm{O}\right) \delta 2.84(2 \mathrm{H}, \mathrm{d}, \mathrm{J}=20.5$ $\left.\mathrm{Hz},-\mathrm{CH}_{2} \mathrm{P}-\right), 2.93\left(2 \mathrm{H}, \mathrm{d}, \mathrm{J}=20.5 \mathrm{~Hz},-\mathrm{CH}_{2} \mathrm{P}-\right), 6.60(2 \mathrm{H}$, $\mathrm{s}, \mathrm{Ar}), 6.66(\mathrm{H}, \mathrm{s}, \mathrm{Ar})$; ${ }^{31} \mathrm{P}$ NMR $\left(\mathrm{D}_{2} \mathrm{O}\right) \delta 18.85(\mathrm{~m}), 20.29(\mathrm{~m})$; MS (FAB-) (M - H) 280; HRMS (FAB-) calcd 280.0140, found
280.0127; HPLC retention time 4.1 min (purity >98\%) using solvent system A, 7.8 min (>98\% purity) using solvent system B.

Tetraethyl 4-Aminophenylphosphonate (28). A mixture of $0.69 \mathrm{~g}(4.0 \mathrm{mmol})$ of 4 -bromoaniline, $0.57 \mathrm{~mL}(4.4 \mathrm{mmol})$ of diethyl phosphite, $0.61 \mathrm{~mL}(4.4 \mathrm{mmol})$ of triethylamine and $0.23 \mathrm{~g}(0.2 \mathrm{mmol})$ of tetrakis(triphenylphosphine)palladium(0) in $1 \mathrm{~mL}$ of anhydrous toluene was heated at $90{ }^{\circ} \mathrm{C}$ for 16 h under $\mathrm{N}_{2}$ atmosphere. After cooling, $10 \mathrm{~mL}$ of diethyl ether was added, and the precipitate was filtered off. The filtrate was concentrated and purified with preparative thin-layer chromatography $\left(\mathrm{CHCl}_{3} / \mathrm{MeOH}=20 / 1\right)$ and crystallized in diethyl ether to give $0.18 \mathrm{~g}$ of $\mathbf{2 8}$ as a white solid (18\%): ${ }^{1 \mathrm{H}}$ $\operatorname{NMR}\left(\mathrm{CDCl}_{3}\right) \delta 1.31\left(6 \mathrm{H}, \mathrm{t}, \mathrm{J}=6.8 \mathrm{~Hz}, 2 \times-\mathrm{CH}_{3}\right), 3.98-4.14$ $\left(4 \mathrm{H}, \mathrm{m},-\mathrm{OCH}_{2}-\right), 6.69,6.71(2 \mathrm{H}, 2 \mathrm{~d}, \mathrm{~J}=8.8 \mathrm{~Hz}, \mathrm{Ar}), 7.56$, $7.61(2 \mathrm{H}, 2 \mathrm{~d}, \mathrm{~J}=8.8 \mathrm{~Hz}, \mathrm{Ar})$; ${ }^{31} \mathrm{P} N M R\left(\mathrm{CDCl}_{3}\right) \delta 21.24(\mathrm{~m})$; MS (EI) $\left(M^{+}\right)$229; HRMS (EI) calcd 229.0868, found 229.0867.

4-Aminophenylphosphonic Acid (29). To a solution of $40 \mathrm{mg}$ of $28(0.18 \mathrm{mmol})$ in $2 \mathrm{~mL}$ of anhydrous $\mathrm{CH}_{3} \mathrm{CN}$ was added $0.12 \mathrm{~mL}$ of trimethylsilyl bromide $(0.88 \mathrm{mmol})$ at $25^{\circ} \mathrm{C}$ under $\mathrm{N}_{2}$ atmosphere. The mixture was stirred for $12 \mathrm{~h}$, and the solvent was removed by $\mathrm{N}_{2}$ stream. The residue was partitioned between diethyl ether and $0.5 \mathrm{M}$ ammonium bicarbonate solution, and the aqueous fraction was purified with the same ion exchange col umn chromatography in general procedure to give $30 \mathrm{mg}$ of $\mathbf{2 9}$ (99\% yield): ${ }^{1} \mathrm{H}$ NMR $\left(\mathrm{D}_{2} \mathrm{O}\right) \delta$ 7.38, $7.39(2 \mathrm{H}, 2 \mathrm{~d}, \mathrm{~J}=8.8 \mathrm{~Hz}, \mathrm{Ar}), 7.80,7.84(2 \mathrm{H}, 2 \mathrm{~d}, \mathrm{~J}=8.8$ $\mathrm{Hz}, \mathrm{Ar})$; ${ }^{31 \mathrm{P} N M R}\left(\mathrm{D}_{2} \mathrm{O}\right) \delta 12.00(\mathrm{~m}) ; \mathrm{MS}(\mathrm{FAB}+)(\mathrm{M}+\mathrm{H}) 174$; HRMS (FAB +) calcd 174.0320, found 174.0327; HPLC retention time 2.1 min (purity $>98 \%$ ) using solvent system $A, 3.3$ min (>98\% purity) using solvent system $B$.

Pharmacology. Precautions must be taken to shield these P2X antagonists from light. In aqueous solution and upon exposure to light, azo-containing derivatives, such as $\mathbf{1}$ and $\mathbf{2}$, had half-lives of several hours (G. Semple, unpublished observations). Both compounds were stable for days in solution when kept in the dark and for over a month as solids in clear bottles on the shelf.

Antagonist Activity at $\mathbf{P} 2 \mathbf{X}$ Receptors. At rat $\mathbf{P} 2 \mathbf{X}_{\mathbf{1}}$, $\mathbf{P} \mathbf{2} \mathbf{X}_{\mathbf{2}}$, or $\mathbf{P} \mathbf{2 X}_{\mathbf{3}}$ receptors: Xenopus oocytes were harvested and prepared as previously described. ${ }^{26}$ Defolliculated oocytes were injected cytosolically with rat $\mathrm{P} 2 \mathrm{X}_{1}, \mathrm{P} 2 \mathrm{X}_{2}$ or $\mathrm{P} 2 \mathrm{X}_{3}$ receptor cRNA $(40 \mathrm{~nL}, 1 \mu \mathrm{g} / \mathrm{mL})$, incubated for $24 \mathrm{~h}$ at $18^{\circ} \mathrm{C}$ in Barth's solution and kept for up to 12 days at $4{ }^{\circ} \mathrm{C}$ until used in electrophysiological experiments.

ATP-activated membrane currents $\left(\mathrm{V}_{\mathrm{h}}=-90 \mathrm{mV}\right)$ were recorded from cRNA-injected oocytes using the twin-electrode voltage-clamp technique (Axoclamp 2B amplifier). Voltage recording (1-2 $\mathrm{M} \Omega$ tip resistance) and current-recording microelectrodes (5 $\mathrm{M} \Omega$ tip resistance) were filled with $3.0 \mathrm{M}$ $\mathrm{KCl}$. Oocytes were held in an electrophysiological chamber and superfused with Ringer's solution ( $5 \mathrm{~mL} / \mathrm{min}$, at $18{ }^{\circ} \mathrm{C}$ ) containing (mM) N NCl, 110; KCl, 2.5; HEPES (N-[2-hydroxyethyl]piperazine- $\mathrm{N}^{\prime}$-[3-propanesulfonic acid]), 5; $\mathrm{BaCl}_{2}, 1.8$, adjusted to $\mathrm{pH}$ 7.5.

ATP (at the $\mathrm{EC}_{70}$ values in $\mu \mathrm{M}$ for respective subtypes: $\mathrm{P} 2 \mathrm{X}_{1}, 1 ; \mathrm{P} 2 \mathrm{X}_{2}, 10 ; \mathrm{P} 2 \mathrm{X}_{3}, 3$ ) was superfused over the oocytes for $60-120 \mathrm{~s}$ then washed out for a period of $20 \mathrm{~min}$. For inhibition curves, data were normalized to the current evoked by ATP, at pH 7.5. Test substances were added for $20 \mathrm{~min}$ prior to ATP exposure; all compounds were tested for reversibility of their effects. The concentration required to inhibit the ATP response by $50 \%\left(\mathrm{IC}_{50}\right)$ was taken from Hill plots constructed using the formula: $\log \left(I / I_{\max }-I\right)$, where I is the current evoked by ATP in the presence of an antagonist. Data are presented as mean \pm SEM $(n=4)$ for data from different batches of oocytes.

$\mathbf{P}_{2} \mathbf{X}_{7}$ Receptor Channel Activation. Cation channel activity of $\mathrm{P} 2 \mathrm{X}_{7}$ receptors was assayed as the ATP-induced loss of intracellular $\mathrm{K}^{+}$in adherent HEK 293 cells stably expressing

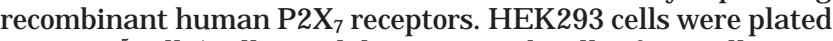
at $5 \times 10^{5} \mathrm{cells} /$ well on polylysine-coated wells of 12 -well tissue culture chambers and grown to $90 \%$ confluence in DMEM (Dulbecco's modified eagle medium) plus $10 \%$ calf serum. The 
growth medium was removed and replaced with $1 \mathrm{~mL}$ of divalent cation-containing saline consisting of $130 \mathrm{mM} \mathrm{NaCl}$, $5 \mathrm{mM} \mathrm{KCl}, 20 \mathrm{mM}$ NaHEPES (pH 7.5), $1 \mathrm{mM} \mathrm{MgCl} 2,1.5 \mathrm{mM}$ $\mathrm{CaCl}_{2}, 10 \mathrm{mM}$ glucose, and $0.1 \%$ BSA. An alternative, divalent cation-free medium with the same basic composition but lacking the $\mathrm{MgCl}_{2}$ and $\mathrm{CaCl}_{2}$ was also tested. The cell monolayers were treated with the indicated concentrations of pyridoxal-phosphate derivative prior to the addition of $3 \mathrm{mM}$ ATP (a maximal concentration of agonist under these ionic conditions). After a $10-$ min incubation at $37{ }^{\circ} \mathrm{C}$, the assay medium was rapidly and completely aspirated and replaced with $1 \mathrm{~mL} 10 \% \mathrm{HNO}_{3}$. After a 2-h extraction, the total $\mathrm{K}^{+}$ content of the nitric acid extract was assayed by atomic absorbance spectrophotometry. The extent of ATP-induced $\mathrm{K}^{+}$ efflux (plus or minus the various antagonists) was measured relative to the $\mathrm{K}^{+}$content of untreated cells. The $\mathrm{K}^{+}$content of control HEK cells bathed in divalent cation-containing saline

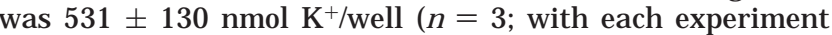
performed in duplicate for all tested conditions). Following a 10-min stimulation with ATP, the $\mathrm{K}^{+}$content was reduced to $141 \pm 68 \mathrm{nmol} /$ well. For cells bathed in divalent cation-free medium, the $\mathrm{K}^{+}$content was $512 \pm 60 \mathrm{nmol} \mathrm{K}^{+} /$well, while the $\mathrm{K}^{+}$content of the ATP-stimulated cells was $135 \pm 36 \mathrm{nmol} /$ well. Relative efficacies of the different antagonists were calculated as the percentage inhibition of the ATP-induced $\mathrm{K}^{+}$ loss in the absence of any pyridoxal-phosphate derivatives.

P 2X $\mathbf{7}_{\mathbf{7}}$ Receptor-Dependent Pore Formation. The poreforming function of $\mathrm{P}_{2} \mathrm{X}_{7}$ receptors was assayed as described previously in suspended HEK293 cells stably expressing recombinant human $\mathrm{P} 2 \mathrm{X}_{7}$ receptors. ${ }^{29}$ Following trypsinization, the cells were suspended in the divalent cation-free saline described above. After transfer of a 1.5-mL aliquot of cell suspension to a thermostated $\left(37^{\circ} \mathrm{C}\right)$, stirred fluorimeter cuvette, $20 \mu \mathrm{M}$ ethidium bromide was added. The cells were then treated with the indicated concentrations of pyridoxalphosphate derivative prior to the addition of $300 \mu \mathrm{M}$ ATP (a supramaximal concentration of agonist under these ionic conditions). The rates of ethidium influx were fluorimetrically monitored and calculated as described previously. ${ }^{29}$ Relative efficacies of the different antagonists were calculated as the percentage inhibition of the ATP-induced rate of ethidium influx in the absence of any pyridoxal-phosphate derivatives.

Phospholipase C Assay at P2Y Receptors. P2Y 1 receptor-promoted stimulation of inositol phosphate formation by 2-MeSADP (10 nM) was measured in turkey erythrocyte membranes as previously described.27,28 The values were averaged from 3-8 independent determinations. Briefly, $1 \mathrm{~mL}$ of washed turkey erythrocytes was incubated in inositol-free medium (DMEM; Gibco) with $0.5 \mathrm{mCi}$ of $2-\left[{ }^{3} \mathrm{H}\right]$ myo-inositol (20 $\mathrm{Ci} / \mathrm{mmol}$; American Radiolabeled Chemicals Inc., St. Louis, MO) for $18-24 \mathrm{~h}$ in a humidified atmosphere of $95 \%$ air $5 \%$ $\mathrm{CO}_{2}$ at $37^{\circ} \mathrm{C}$. E rythrocyte ghosts were prepared by rapid lysis in hypotonic buffer $(5 \mathrm{mM}$ sodium phosphate, $\mathrm{pH} 7.4,5 \mathrm{mM}$ $\mathrm{MgCl}_{2}, 1 \mathrm{mM}$ EGTA) as described. ${ }^{26}$ Phospholipase $\mathrm{C}$ activity was measured in $25 \mu \mathrm{L}$ of [ ${ }^{3} \mathrm{H}$ ] inositol-labeled ghosts (ca. 175 $\mu \mathrm{g}$ of protein, $200-500000 \mathrm{cpm} /$ assay) in a medium containing $424 \mu \mathrm{M} \mathrm{CaCl}_{2}, 0.91 \mathrm{mM} \mathrm{MgSO}_{4}, 2 \mathrm{mM}$ EGTA, $115 \mathrm{mM} \mathrm{KCl}, 5$ $\mathrm{mM} \mathrm{KH}{ }_{2} \mathrm{PO}_{4}$, and $10 \mathrm{mM}$ Hepes, $\mathrm{pH}$ 7.0. Assays $(200 \mu \mathrm{L}$ final volume) contained $1 \mu \mathrm{M}$ GTP $\gamma \mathrm{S}$ and the indicated concentrati ons of nucleotide analogues. Ghosts were incubated at $30^{\circ} \mathrm{C}$ for $5 \mathrm{~min}$, and total $\left[{ }^{3} \mathrm{H}\right]$ inositol phosphates were quantitated by anion-exchange chromatography as previously described. ${ }^{27,28}$

Acknowledgment. S.G.B. thanks Gilead Sciences (Foster City, CA) for funding. We thank Dr. Lewis Pannell and Wesley White for determination of highresolution mass spectroscopy and NMR. We thank Graeme Semple Ph.D., AstraZeneca R\&D, Mölndal, Sweden, for alerting us to the instability of azo-containing P 2 antagonists. This work was supported by USPHS Grants GM38213, HL34322, and HL54889.

\section{References}

(1) North, R. A.; Barnard, E. A. Nucleotide receptors. Curr. Opin. Neurobiol. 1997, 7, 346-357.

(2) Ralevic, V.; Burnstock, G. Receptors for purines and pyrimidines Pharmacol. Rev. 1998, 50, 413-492.

(3) Abbracchio, M. P.; Burnstock, G. Purinergic signaling: pathophysiological roles. J pn. J . Pharmacol. 1998, 78, 113-145.

(4) Communi, D.; Boeynaems, J. M. Receptors responsive to extracellular pyrimidine nucleotides. Trends Pharmacol. Sci. 1997, 18, 83-86.

(5) Burnstock, G.; King, B. F. Numbering of cloned P2 purinoceptors Drug Dev. Res. 1996, 38, 67-71.

(6) Fredholm, B. B.; Abbracchio, M. P.; Burnstock, G.; Dubyak, G R.; Harden, T. K.; J acobson, K. A.; Schwabe, U.; Williams, M. Towards a revised nomenclature for $\mathrm{P} 1$ and $\mathrm{P} 2$ receptors. Trends Pharmacol. Sci. 1997, 18, 79-82.

(7) Communi, D.; Govaerts, C.; Parmentier, M.; Boeynaems, J . M Cloning of a human purinergic $\mathrm{P} 2 \mathrm{Y}$ receptor coupled to phospholipase C and adenylyl cyclase. J. Biol. Chem. 1997, 272, 31969-31973.

(8) King, B. F.; Townsend-Nicholson, A.; Burnstock, G. Metabotropic Receptors for ATP and UTP: Exploring the Correspondence Between Native and Recombinant Nucl eotide Receptors. Trends Pharmacol. Sci. 1998, 19, 506-514.

(9) J acobson, K. A.; Knutsen, L. J. S. P1 and P2 purine and pyrimidine receptors. Handbk. Exp. Pharmacol., in press.

(10) Burnstock, G.; Wood, J . N. Purinergic receptors - their role in nociception and primary afferent neurotransmission. Curr. Opin Neurobiol. 1996, 6, 526-532.

(11) Cook, S. P.; Vulchanova, L.; Hargreaves, K. M.; Elde, R. McCleskey, E. W. Distinct ATP receptors on pain-sensing and stretch-sensing neurons. Nature 1997, 387, 505-508.

(12) Di Virgilio, F.; Falzoni, S.; Mutini, C.: Sanz, J . M.; Chiozzi, P. Purinergic $\mathrm{P}_{2} \mathrm{X}_{7}$ receptor: A pivotal role in inflammation and immunomodulation. Drug Dev. Res. 1998, 45, 207-213.

(13) Lambrecht, G.; Ardanuy, U.; Bäumert, H. G.; Bo, X.; Hoyle, C. H. V.; Nickel, P.; Pfaff, O.; Ralevic, V.; Windschief, U.; Ziganshin A. U.; Ziyal, R.; Mutscheler, E.; Burnstock, G. Design and pharmacological characterization of selective P2-purinoceptor antagonists. In Perspectives in Receptor Research; Giardinà, D. Piergentili, S., Pigini, M., Eds.; Elsevier Science Publishers: Amsterdam, 1996; pp 337-350.

(14) J acobson, K. A.; Kim, Y.-C.; Wildman, S. S.; Mohanram, A.; Harden, T. K.; Boyer, J. L.; King, B. F.; Burnstock, G. A pyridoxine cyclic-phosphate and its 6-arylazo-derivative selectively potentiate and antagonize activation of $\mathrm{P}_{2} \mathrm{X}_{1}$ receptors. J. Med. Chem. 1998, 41, 2201-2206.

(15) Boyer, J. L.; Zohn, I. E.; J acobson, K. A.; Harden, T. K. Differential effects of $\mathrm{P}_{2}$-purinergic receptor antagonists on phospholipase C- and adenylyl cyclase-coupled $\mathrm{P}_{2 y}$ purinergic receptors. Br. J . Pharmacol. 1994, 113, 614-620.

(16) Lambrecht, G.; Friebe, T.; Grimm, U.; Windscheif, U.; Bungardt, E.: Hildebrandt, C.; Baumert, H. G.; Spatzkumbel, G.; Mutschler, E. PPADS, a Novel Functionally Selective Antagonist of P2 Purinoceptor-Mediated Responses. Eur.J . Pharmacol. 1992, 217, 217-219.

(17) Ziganshin, A. U.; Hoyle, C.; Bo, X. N.; Lambrecht, G.; M utschler, E.; Bäumert, H. G.; Burnstock, G. PPADS selectively antagonizes $\mathrm{P}_{2 \times}$ purinoceptor-mediated responses in the rabbit urinarybladder. Br. J. Pharmacol. 1993, 110, 1491-1495.

(18) Ziganshin, A. U.; Hoyle, C. H. V.; Lambrecht, G.; Mutschler, E.; Baumert, H. G.; Burnstock, G. Sel ective antagonism by PPADS at P2X-purinoceptors in rabbit isolated blood vessels. Br. J. Pharmacol. 1994, 111, 923-929.

(19) McLaren, G. J .; Lambrecht, G.; Mutschler, E.; Baumert, H. G.; Sneddon, P.; Kennedy, C. Investigation of the actions of PPADS, a novel of P2X-purinoceptor antagonist, in the guinea-pig isolated vas deferens. Br. J . Pharmacol. 1994, 111, 913-917.

(20) Windscheif, U.; Ralevic, V.; Bäumert, H. G.; Mutschler, E.; Lambrecht, G.; Burnstock, G. Vasoconstrictor and vasodilator responses to various agonists in the rat perfused mesenteric arterial bed - selective-inhibition by PPADS of contractions mediated via P2X-purinoceptors. Br. J . Pharmacol. 1994, 113, 1015-1021.

(21) Chessell, I. P.; Simon, J .; Hibell, A. D.; Michel, A. D.; Barnard, E. A.; Humphrey, P. P. A. Cloning and functional characterization of the mouse P2X7 receptor. FEBS Lett. 1998, 439, 26-30.

(22) Trezise DJ , Kennedy I \& Humphrey PPA. The use of antagonists to characterize the receptors mediating depolarization of the rat isolated vagus nerve by alpha, beta-methylene adenosine 5' triphosphate. Br. J. Pharmacol. 1994, 112, 282-288.

(23) Rae, M. G.; Rowan, E. G.; Kennedy, C. Pharmacological properties of $\mathrm{P} 2 \mathrm{X}_{3}$-receptors present in neurones of the rat dorsal root ganglia. Br. J . Pharmacol. 1998, 124, 176-80.

(24) Grubb, B. D.; Evans, R. J . Characterization of cultured dorsal root ganglion neuron P2X receptors. Eur. J . Neurosci. 1999, 11, 149-154. 
(25) Kim, Y.-C.; Camaioni, E.; Ziganshin, A. U.; J i, X.-J .; King, B. F.; Wildman, S. S.; Rychkov, A.; Yoburn, J .; Kim, H.; Mohanram A.; Harden, T. K.; Boyer, J . L.; Burnstock, G.; J acobson, K. A. Synthesis and structure activity relationships of pyridoxal-6azoaryl-5'-phosphate and phosphonate derivatives as $\mathrm{P} 2$ receptor antagonists. Drug Dev. Res. 1998, 45, 52-66.

(26) King, B. F.; Wildman, S. S.; Ziganshina, L. E.; Pintor, J .; Burnstock, G. Effects of extracellular pH on agonism and antagonism at recombinant $\mathrm{P}_{2} \mathrm{X}_{2}$ receptors. $\mathrm{Br}$. J . Pharmacol. 1997, 121, 1445-1453.

(27) Harden, T. K.; Hawkins, P. T.; Stephens, L.; Boyer, J . L.; Downes, P. Phosphoinositide hydrolysis by guanosine 5'-(gammathio)triphosphate-activated phospholipase $\mathrm{C}$ of turkey erythrocyte membranes. Biochem. J . 1988, 252, 583-593.

(28) Camaioni, E.; Boyer, J. L.; Mohanram, A.; Harden, T. K.; J acobson, K. A. Deoxyadenosine-bisphosphate derivatives as potent antagonists at P2Y 1 receptors. J . Med. Chem. 1998, 41, 183-190.

(29) Humphreys, B. D.; Virginio, C.; Surprenant, A.; Rice, J .; Dubyak, G. R. I soquinolines as antagonists of the $\mathrm{P} 2 \mathrm{X}_{7}$ nucleotide receptor: high selectivity for the human versus rat receptor homologues. Mol. Pharmacol. 1998, 54, 22-32.

(30) Charlton, S. J .; Brown, C. A.; Weismann, G. A., Turner, J . T.; Erb, L.; Boarder, M. R. PPADS and Suramin as Antagonists at Cloned $\mathrm{P}_{2 y^{-}}$and $\mathrm{P}_{2 u^{-}}$-Receptors. Br. J . Pharmacol. 1996, 118, 704-710.

(31) Brown, C. A.; Charlton, S. J .; Boarder, M. R. Enhancement of the Response to Purinergic Agonists in $\mathrm{P}_{2} \mathrm{Y}_{1}$ Transfected $1321 \mathrm{~N} 1$ Cells by Antagonists Suramin and PPADS. Br. J . Pharmacol. 1997, 120, 1049-1052.

(32) Soto F, Garcia-Guzman M \& Stuhmer W. Cloned ligand-gated channels activated by extracellular ATP (P2X receptors). J. Membr. Biol. 1997, 160, 91-100.

(33) Buell G, Lewis C, Collo G, North RA \& Surprenant A. An antagonist-insensitive $\mathrm{P} 2 \mathrm{X}$ receptor expressed in epithelia and brain. EMBO J . 1996, 15, 55-62.

(34) Collo, G.; North, R. A.; Kawashima, E.; Merlo-Pich, E.; Neidhart, S.; Surprenant, A.; Buell, G. Cloning of $\mathrm{P} 2 \mathrm{X}_{5}$ and $\mathrm{P} 2 \mathrm{X}_{6}$ receptors and the distribution and properties of an extended family of ATPgated ion channels. J. Neurosci. 1996, 16, 2495-2507.
(35) Garcia-Guzman, M.; Stuhmer, W.; Soto, F. Molecular characterization and pharmacological properties of the human P2X purinoceptor. Brain Res. (Mol. Brain Res.) 1997, 47, 59-66.

(36) Townsend-Nicholson, A.; King, B. F.; Wildman, S. S.; Burnstock, G. Molecular cloning, functional characterization and possible cooperativity between the murine $\mathrm{P} 2 \mathrm{X}_{4}$ and $\mathrm{P} 2 \mathrm{X}_{4 a}$ receptors. Brain Res. (Mol. Brain Res.) 1999, 64, 246-254.

(37) Lewis, C.; Neidhart, S.; Holy, C.; North, R. A.; Buell, G.; Surprenant, A. Coexpression of $\mathrm{P} 2 \mathrm{X}_{2}$ and $\mathrm{P} 2 \mathrm{X}_{3}$ receptor subunits can account for ATP-gated currents in sensory neurons. Nature 1995, 377, 432-435.

(38) Khakh, B. S.; Michel, A.; Humphrey, P. P. A. Estimates of antagonist affinities at $\mathrm{P} 2 \mathrm{X}$ purinoceptors in rat vas deferens. Eur. J . Pharmacol. 1994, 263, 301-309.

(39) Lambrecht, G.; Rettinger, J .; Baumert, H.; Czeche, S.; Damer, S.; Ganso, M.; Hildebrandt, C.; Niebel, B.; Schmalzing, G.; Mutschler, E. The pyridoxal-6-naphthylazo-5'-phosphate derivative PPNDS potently antagonizes activation of $\mathrm{P}_{2} \mathrm{X}_{1}$ receptors. In press.

(40) Alexander, K.; Niforatos, W.; Bianchi, B.; Burgard, E. C.; Lynch, K. J .; Kowaluk, E. A.; J arvis, M. F.; van Biesen, T. Allosteric modulation and accelerated resensitization of human $\mathrm{P} 2 \mathrm{X}_{3}$ Receptors by Cibacron blue. J . Pharmacol. Exp. Ther. 1999, 291 $1135-1142$.

(41) Hoffmann, C.; Pradel, G.; Heine, P.; J acobson, K. A.; Zimmermann, H. Inhibition of ecto-ATPase and ecto-Apyrase by pyridoxal phosphate-related compounds. Drug Dev. Res. 2000, in press.

(42) Ziganshin, A. U.; Ziganshina, L. E.; King, B. F.; Pintor, J .; Burnstock, G. Effects of P2 purinoceptor antagonists on degradation of adenine nud eotides by ecto-nucleotidases in foll iculated oocytes of Xenopus Iaevis. Biochem. Pharmacol. 1996, 51, 897901.

(43) Damer S.; Niebel B.; Czeche S.; Nickel P.; Ardanuy U.; Schmalzing G.; Rettinger J .; Mutschler E.; Lambrecht G. NF 279: a novel potent and selective antagonist of $\mathrm{P} 2 \mathrm{X}$ receptor-mediated re sponses. Eur. J . Pharmacol. 1998, 350, R5-6.

J M9904203 